IZA DP No. 6481

Food Security and Wheat Prices in Afghanistan:

A Distribution-Sensitive Analysis of Household-Level Impacts

Anna D'Souza

Dean Jolliffe

April 2012 


\title{
Food Security and Wheat Prices in Afghanistan: A Distribution-Sensitive Analysis of Household-Level Impacts
}

\author{
Anna D'Souza \\ Economic Research Service, USDA \\ Dean Jolliffe \\ World Bank \\ and IZA
}

Discussion Paper No. 6481

April 2012

IZA

P.O. Box 7240

53072 Bonn

Germany

Phone: +49-228-3894-0

Fax: +49-228-3894-180

E-mail: iza@iza.org

\begin{abstract}
Any opinions expressed here are those of the author(s) and not those of IZA. Research published in this series may include views on policy, but the institute itself takes no institutional policy positions.

The Institute for the Study of Labor (IZA) in Bonn is a local and virtual international research center and a place of communication between science, politics and business. IZA is an independent nonprofit organization supported by Deutsche Post Foundation. The center is associated with the University of Bonn and offers a stimulating research environment through its international network, workshops and conferences, data service, project support, research visits and doctoral program. IZA engages in (i) original and internationally competitive research in all fields of labor economics, (ii) development of policy concepts, and (iii) dissemination of research results and concepts to the interested public.
\end{abstract}

IZA Discussion Papers often represent preliminary work and are circulated to encourage discussion. Citation of such a paper should account for its provisional character. A revised version may be available directly from the author. 


\section{ABSTRACT}

\section{Food Security and Wheat Prices in Afghanistan: A Distribution-Sensitive Analysis of Household-Level Impacts ${ }^{*}$}

We investigate the impact of increases in wheat flour prices on household food security using unique nationally-representative data collected in Afghanistan from 2007 to 2008. We use a new estimator, the Unconditional Quantile Regression (UQR) estimator, based on influence functions to examine the marginal effects of price increases at different locations on the distributions of several food security measures. UQR estimates reveal that the negative marginal effect of a price increase on food consumption is two and a half times larger for households that can afford to cut the value of food consumption ( $75^{\text {th }}$ quantile) than for households at the bottom ( $25^{\text {th }}$ quantile) of the food-consumption distribution. Similarly, households with diets high in calories reduce intake substantially, but those at the bottom of the calorie distribution ( $25^{\text {th }}$ quantile) make very small changes in intake as a result of the price increases. In contrast, households at the bottom of the dietary diversity distribution make the largest adjustments in the quality of their diets, since such households often live at subsistence levels and cannot make large cuts in caloric intake without suffering serious health consequences. These results provide empirical evidence that when faced with staplefood price increases, food-insecure households sacrifice quality (diversity) in order to protect calories. The large differences in behavioral responses of households that lie at the top and bottom of these distributions suggest that policy analyses relying solely on OLS estimates may be misleading.

JEL Classification: D12, I3

Keywords: Afghanistan, food prices, wheat, food security, nutrition, poverty, quantile regression, influence functions

Corresponding author:

Dean Jolliffe

The World Bank

1818 H Street NW

Washington, DC 20433

USA

E-mail: djolliffe@worldbank.org

\footnotetext{
* The authors are grateful to Central Statistics Organization, Government of Afghanistan (GoA), for granting access to the data for poverty research. Findings from this analysis provide background information for the World Bank's poverty assessment for Afghanistan, and have also informed the GoA Ministry of Economy. Jolliffe gratefully acknowledges support from the World Bank's Research Support Budget. The authors wish to thank for comments Amanullah Assil, Maurice Landes, Ismail Rahimi, Silvia Redaelli, Byron Ponce-Segura, Nick Wilson, and seminar participants at the World Bank, Kabul office; ERS, USDA; and the 2011 AAEA Annual Meeting. D'Souza is a Research Economist at ERS, USDA; Jolliffe is a Senior Economist at the World Bank, and also holds affiliations with the Institute for the Study of Labor (IZA) in Bonn and with the National Poverty Center (NPC) at the Ford School of Public Policy, University of Michigan. The views expressed here are those of the authors and may not be attributed to ERS, the USDA, the World Bank, IZA, or NPC.
} 


\section{Introduction}

Wheat is the staple food in Afghanistan, contributing approximately 54 percent of average daily caloric intake. In 2008 due to a combination of international (increasing global food prices), regional (export bans in key trading partners like Pakistan), and domestic (drought) factors, domestic wheat grain and flour prices approximately doubled. These sharp price increases constituted a serious economic shock to Afghan households, who spend the majority of their budgets on food. D'Souza and Jolliffe (2012) find that the price shock had a measurable impact on household food security across Afghanistan. Using ordinary least squares (OLS), they show that households reduced the value of food consumption in response to wheat flour price increases and that this reduction in the value of consumption is the result of reducing the quality (dietary diversity) and quantity (calories) of food consumed in approximately equal proportions. Such declines in consumption and nutrition indicators can have serious implications. Even short bouts of poor nutrition can have longterm repercussions, particularly for vulnerable populations such as children, lactating women and the elderly and those on the cusp of poverty and/or malnutrition (UNICEF, 2009). These bouts may exacerbate already high levels of malnutrition; Afghanistan has the highest prevalence of stunting in the world among children under five years old (UNICEF, 2009).

For the purposes of examining food security, or indeed any measure where the policy focus is on a particular portion of the distribution (such as the lower tail), or a particular threshold on the range of values (such as a poverty line or some fixed nutritional benchmark), the OLS estimator can be a potentially misleading tool. OLS constrains the behavioral response of households to be constant over the entire distribution. Specifically, OLS analysis provides an estimate of the (constant) partial derivative of the mean of the dependent variable with respect to changes in the independent variable. However, if we believe that households at different points of the distribution employ different coping strategies to deal with shocks, then it is essential to disaggregate the estimated behavioral responses in thinking about policy prescriptions.

The Quantile Regression (QR) estimator is frequently used to relax the assumption of a constant marginal response by allowing the responses to vary across the distribution of the dependent variable after conditioning on the observed covariates (for example, see Chamberlain (1994)). A disadvantage of this estimator is that it is based on the conditional population distribution and typically policymakers want to know the response over the 
unconditional distribution. For example, policymakers may be interested in knowing how price shocks affect caloric intake for households at the bottom $25^{\text {th }}$ percent of the calorie distribution of the total population, before conditioning on factors such as location or socioeconomic status. Such information can be valuable in targeting safety net and povertyalleviation programs, as well as allocating resources more generally.

In this paper we utilize a recent innovation in quantile regression analysis - the Unconditional Quantile Regression (UQR) estimator proposed by Firpo, Fortin and Lemieux (2009b) - to examine the impact of the wheat flour price shocks on several measures of food security. The UQR estimator uses influence functions to estimate the behavioral responses at specific quantiles of the unconditional distribution of the dependent variable. We compare OLS estimates to the UQR estimates at the $25^{\text {th }}, 50^{\text {th }}, 75^{\text {th }}$ quantiles to examine whether the effects differ in informative ways across the distribution. We also examine the marginal effects at quantiles corresponding to thresholds that are policy or nutritional relevant, e.g., the commonly used nutritional benchmark of 2,100 kilocalories per person per day. Measuring responses at these thresholds can help to better inform policymakers of how households on the cusp of poverty and/or malnutrition are affected by price increases. Such information may be particularly salient in a conflict-ridden country like Afghanistan, where a large portion of the population lives close to subsistence levels or in poverty; the national poverty rate for 2007-08 was 36\% (M. o. E. Islamic Republic of Afghanistan, and the World Bank Economic Policy and Poverty Sector, 2010).

We find disparities in the behavioral responses of households to increases in the price of wheat flour based on where the household lies on the unconditional distribution of the particular food security measure of interest. While the OLS estimates demonstrate the basic quality-quantity tradeoff that households must make (i.e., reducing dietary diversity to buffer the impact of declining purchasing power on caloric intake), they mask important differences across households. Households at the top of the food consumption and calorie distributions experience the largest declines in each of these measures, as might have been expected given that these households can afford to cut back. In contrast, households at the bottom of the calorie distribution cannot afford to make substantial cuts to caloric intake since they are close to the minimum daily energy requirements; accordingly, we see a very small price effect for these households. Finally households at the bottom of the dietary diversity distribution - often very poor households - experience large declines in dietary 
diversity as a result of the wheat flour price increases. Since households living at subsistence levels cannot make major cuts to caloric intake, they must adjust the compositions of their diet in order to maintain energy levels.

To the best of our knowledge, this paper is the first to utilize the UQR estimator to examine the impact of food price shocks on household food security. It represents one of a handful of empirical analyses that use nationally-representative household data collected prior to and during a significant price shock. Since such data are extremely rare, most empirical analyses rely on data collected during earlier periods and utilize simulation models to look at the potential impact of the price shock on household welfare. In this analysis, we seek to inform local and national policymakers and development agents working in Afghanistan by providing systematic quantitative analyses of household responses to food price shocks.

\section{Data}

We use consumption and price data from the National Risk and Vulnerability Assessment (NRVA) 2007/08, conducted by the Government of Afghanistan Central Statistics Organization and the Ministry of Rural Rehabilitation and Development. The survey was administered between August 2007 and September 2008 and covered over 20,500 households (over 150,000 individuals) in 2,572 communities in all 34 provinces of Afghanistan. The long time frame made it possible to obtain seasonally-adjusted estimates of household food security and allowed for coverage of conflict-affected areas.

The sample was selected based on a stratified, multi-stage design. The survey was stratified explicitly geographically and implicitly over time. ${ }^{1}$ The 11 provinces with the most populous provincial centers were each stratified into urban and rural areas. The remaining provinces were treated as separate rural strata, and the nomadic Kuchi population was treated as a separate stratum. The stratification resulted in 46 domains or strata. In the first stage of selection, 2,441 primary sampling units (PSU) from urban and rural settled populations and 131 PSUs from Kuchi populations were drawn. In the second and final stage, eight households were selected from each PSU.

\footnotetext{
1 The population frame is based on a 2003-05 national household listing.
} 
The implicit stratification over time is a key element of the survey design. The population frame was sorted both spatially and temporally to ensure that (with a systemic interval selection) the selected sample would be seasonally representative. (See Kish (1965, pp. 235-236) for a discussion of implicit stratification.) Thus each quarterly sample of the NRVA survey is representative at the national level. In a country where agriculture is an important form of livelihood, seasonal variations in consumption patterns are to be expected; thus it is critical to capture nationally-representative measures of household food security throughout the year. (Online appendix Table A1 displays key demographic, educational and health, and infrastructure indicators across the four quarters. While we observe some statistical differences in means across quarters, there is little evidence of systematic differences in the samples based on these generally time-invariant characteristics.) Additionally, the year-long fieldwork enabled enumerators to access households in conflict zones without compromising the survey design. Specifically, enumerators would try to secure permission informally from local leaders; when a PSU was considered too insecure to interview at the scheduled time, it would not be replaced immediately, but would be reconsidered at a later date within the quarter.

The NRVA consists of household and community questionnaires and a district market price survey. ${ }^{2}$ In this analysis, we exploit two key elements - the food consumption data and the price data. The consumption data include the frequency and quantity of consumption of 91 food items consumed over the previous week, including food bought on the market, produced, or obtained through other methods like food aid and gifts. The NRVA's broad coverage of foods, including seasonal varieties, allows for better calculation of caloric and nutrient intake than surveys with fewer items. The price data include prevailing prices of the food items included in the consumption section, as well as domestic and imported grains and fuel. The local price data are important to obtain accurate estimates of price effects in a mountainous country with poor infrastructure, where transportation and transaction costs vary greatly.

Measures of food security

\footnotetext{
2 The household questionnaire includes 20 sections -6 administered by female interviewers to female household members and 14 administered by male interviewers to the male household head. In Afghanistan, it is important that interviews be conducted among individuals of the same sex.
} 
"Food security exists when all people, at all times, have physical and economic access to sufficient, safe and nutritious food that meets their dietary needs and food preferences for an active and healthy life" (Food and Agricultural Organization, 2008, p. 1). It includes four main factors: availability, access, utilization, and stability. Availability refers to the physical existence of food, which relates to production, stocks and trade. Access refers to a household's ability to obtain food, which depends on income, prices, and market access. Utilization refers to an individual's ability to process nutrients and energy from food; many factors contribute to food utilization, including dietary diversity and nutrient absorption, intra-household allocation of food, and hygienic preparation. The final factor refers to the stability of the other three factors over time (Food and Agricultural Organization, 2008).

We construct three measures of household food security to be used as dependent variables in the regression analysis: the value of per capita monthly food consumption; per capita daily caloric intake; and household dietary diversity. The first two relate to the access to food and the last one relates to the utilization of food. The value of food consumption is a core component of poverty indictors. Caloric intake is a widely used measure of health and undernutrition; however recent literature suggests that it is not a sufficient indicator of nutritional status, therefore we also include a measure of dietary diversity (Deaton \& Dreze, 2009). Recent research highlights the relationship between child and adult nutritional status and household dietary diversity (Ruel, 2003).

The value of monthly food consumption (in Afghani) is constructed by mapping district price data to food quantity data. ${ }^{3}$ Since not all food items were available in all district markets at all times of the year, we imputed the missing elements to obtain a complete price matrix, which provides prices for those items that households may have produced at home or those that households may have obtained from more distant markets. ${ }^{4}$ The survey includes questions on the percentages of imported wheat and rice the household consumes; we use these responses to calculate price averages for domestic and imported varieties

\footnotetext{
${ }^{3}$ Households are asked for the quantity of foods consumed over the past seven days; these quantities are multiplied by 4.2 to get monthly values.

${ }^{4}$ The imputation process filled in missing values using the first feasible methodology according to the following order: 1) median of that month of the 20 nearest neighbors (weighted by inverse distance); 2) province median of that month; 3) national median of that month; 4) median price of 20 neighboring districts of the quarter (weighted by inverse distance); 5) province median of that quarter; and 6) national median of that quarter.
} 
separately, given large differences in price and quality. Finally, we convert nominal values to real values using a consumer food price index. ${ }^{5}$

We use the FAO Food Composition Tables for the Near East to convert daily food quantities into kilocalories; we then divide by the effective household size to get per capita daily caloric intake. ${ }^{6}$ The effective number of household members incorporates guests eating meals within the home and deducts when members are not regularly eating meals at home. ${ }^{7}$ The effective number of household members is greater than household size for the relatively richer households, and less than household size for the poorest of households. The value of expenditure on food away from home is included in the calculation of the value of food consumption, but not included in the calculation of caloric intake since quantity data on such food was not collected. Food away from home constitutes about two percent of total food expenditure on average; it is less than half a percent for the poorest 20 percent of the population and about four percent for the richest 20 percent of the population.

To measure household dietary diversity, we use the food consumption score (FCS) developed by the World Food Programme (WFP). It is a weighted sum of the frequencies with which households consume foods within eight food groups over the previous week. ${ }^{8}$ The food groups include staples, pulses, vegetables, fruit, meat/fish, milk/dairy, sugar, and oil/fat. Higher scores denote a more varied diet and are suggestive of a higher quality diet with a potential for higher micronutrient intake. The FCS has been used in food security assessments throughout the world. In Afghanistan, the national average is 61. The WFP uses a cutoff of 48 for an acceptable diet in countries where most households consume staples and oil every day. Under this categorization approximately 80 percent of the

\footnotetext{
${ }^{5}$ We use a Laspeyres price index estimated by quarter for each region using the district price data. Real consumption is relative to the chosen base: urban areas in the Central region in quarter one. The capital, Kabul, is located in the Central region.

${ }^{6}$ Spices, water, and 'other' foods do not contribute to total calories. USDA sources were used for a few items that were not available in the FAO tables.

${ }^{7}$ Some studies use household size to calculate per capita amounts. In Afghanistan the custom of sharing meals with guests makes it important to account for guests eating meals from the household cooking pot. The effective household size also incorporates information on household members eating outside the home. Some studies use equivalency scales to account for differences in consumption of adults and children when calculating measures of wellbeing. We opt to include variables for household composition directly into the regression model to control for such differences.

${ }^{8}$ Weights for the food groups range from 0.5 to 4 based on nutrient density. Condiments receive zero nutritional weight. Frequencies are truncated at 7 for each food group. The measure ranges from 0 to 112.
} 
population have acceptable diets; however recent work suggests that the cutoff points for the FCS classifications may be too low (Weismann, Basssett, Benson, \& Hoddinott, 2009).

\section{Sample}

The effective sample size for our analysis is 20,483 households. ${ }^{9}$ Approximately 80 percent of households reside in rural areas. On average, households have 8.6 members living in about 3.6 rooms (or tents for Kuchi populations). The typical household consists of 2.1 men, 2 females, and 4.5 children (under 16). Heads of households are about 45 years old; nearly all are married and most are illiterate.

In the empirical work, we estimate the effects of the wheat flour price increases at the national level, as well as based on a household's access to agricultural land (defined hereafter as agricultural households). This categorization broadly relates to the net seller net buyer distinction in the literature that is discussed in detail below. The vast majority (95 percent) of agricultural households are situated in rural areas. About 67 percent of households in rural areas and 15 percent of households in urban areas have access to agricultural land.

Table 1 displays population averages for the national sample, and for agricultural and nonagricultural households. Afghan households spend about 60 percent of their budgets on food, with agricultural households spending about 65 percent and nonagricultural households spending about 55 percent. Nonagricultural households are better off in terms of total consumption and caloric intake. These patterns are consistent with the typical ruralurban divide observed in many countries. Most nonagricultural households are situated in urban areas which are, on average, richer than rural areas. Agricultural households have statistically higher levels of dietary diversity, though the differences are small; these differences may be due to access to a larger variety of foods through home production.

\footnotetext{
9 The household response rate was $99.8 \%$, and the PSU replacement rate was 3\%. Thirty-two households were dropped due to missing female questionnaires; all of these households are located in four communities, suggesting systematic errors in field operations. Fifty-two households were dropped due to missing consumption data and seven households were dropped due to missing asset data. One household is missing data on household size and is dropped because per capita measures of consumption and food security cannot be calculated.
} 


\section{Price data}

Our analysis focuses on the price of domestic wheat flour, the form of wheat most commonly purchased by households. Most wheat is consumed in the form of naan, local unleavened bread that is prepared by households after purchasing either refined wheat flour or whole grain wheat (Chabot \& Dorosh, 2007). Wheat and other grains represent 48 percent of food expenditure and 70 percent of calories consumed for the national sample.

From 2007 to 2008, wheat flour prices in Afghanistan more than doubled. Figure 1 displays the retail prices of wheat flour in four major urban centers. The price increases were driven by several factors: high international prices; a poor harvest brought on by drought; and export bans in key suppliers such as Pakistan. In the empirical work below, we estimate the marginal effects of the total price increases as we are unable to disentangle the effects of the price increases due to each factor.

Table 2 displays the average prices of wheat flour and other important commodities. ${ }^{10}$ We chose these commodities because they represent several key food groups and because milk, lamb, rice, vegetable oil, and wheat flour make up a large percentage of monthly household food expenditure; for example, the relatively poor $\left(20^{\text {th }}\right.$ to $50^{\text {th }}$ quantile of the total consumption distribution) spend eighty percent of their food expenditure on these five food items. We include kerosene because it is commonly used in cooking.

The differences in commodity prices across subpopulations are typically small (less than four percent), but the differences across quarters are striking (Table 3). Using ANOVA (analysis of variance analysis), we find that 75-85 percent of the total variation in wheat flour prices is explained by variation over the four quarters of the survey year; in contrast, approximately 5 percent of the total variation can be explained by variation across provinces.

\section{Changes in food security over the survey year}

The potential impact of the commodity price increases can be seen in the raw data. Table 4 displays population averages for some key indicators of food security by quarter of the survey. While the nominal values of total consumption and food consumption are relatively

\footnotetext{
${ }^{10}$ Prices are aggregated to the stratum level in order to mitigate potential measurement error in district-level prices. Strata are based on urban and rural designation within provinces.
} 
flat, the decline in household food security can be seen in the changes in the real value of food consumption, as well as in the two nutritional measures. The percentage of the population consuming less than 2100 calories per day increased from 24 in fall 2007 to 34 in summer 2008. Further, according to the Government of Afghanistan, the official poverty rate increased from 23.1 percent in fall 2007 to 46 percent in summer 2008 (M. o. E. Islamic Republic of Afghanistan, and the World Bank Economic Policy and Poverty Sector, 2010). These statistics indicate substantial changes in household wellbeing and in particular, nutritional status. In the empirical work below, we find similar patterns after controlling for a variety of household and environmental factors.

\section{Methodology}

In this section, we first describe the basic model and then discuss our approach to estimating the effects of the wheat flour price increases on various measures of household food security. The basic specification is as follows:

$$
\begin{aligned}
& \log \left(f s_{h}\right)=\beta_{0}+\beta_{1} \log \left(\text { price wheat flour }_{a p q}\right)+\theta \log \left(\text { prices }_{a p q}\right)+\alpha H H_{h}+\delta D I S T_{d q} \\
& +\Pi_{p}+\varepsilon_{h}
\end{aligned}
$$

where $b$ denotes household, $a$ denotes area (urban or rural), $d$ denotes district, $p$ denotes province, and $q$ denotes quarter. $f s$ is one of the three measures of household food security described above. Prices represents a vector of commodity prices, $H H$ represents a vector of household characteristics, DIST represents a vector of district-level variables, $\Pi$ denotes province dummy variables, and $\boldsymbol{\varepsilon}$ is an idiosyncratic error term. ${ }^{11}$

In order to isolate the effect of changes in wheat flour prices, we control for simultaneous price increases in other important commodities since household purchasing decisions are based on relative prices. The price vector includes the prices of milk, lamb, rice, vegetable oil, and kerosene for reasons described above. We include the following household characteristics: dummy for agricultural households (households who report

\footnotetext{
${ }^{11}$ For our OLS estimates, we use a standard Huber-White correction to estimate the sampling variance which allows for correlation of the residuals within PSUs. The standard errors are also corrected for stratification. For estimation of the sampling variance of the UQR estimator, we use a PSU-level bootstrap that accounts for correlation of the residuals within the PSUs, but does not account for the stratification.
} 
owning or operating agricultural land); log values of durable assets, housing and livestock; age of household head; dummy for households in which heads are literate; dummy for households in which heads are married; and, separately, the numbers of men, women and children. We include the household composition variables to control for differences in consumption requirements between children and adults and for economies of scale in consumption. ${ }^{12}$

The asset values are intended to control for wealth effects and are assumed to be quasi-fixed in the short run. ${ }^{13}$ The value of durable goods is estimated based on a detailed inventory of household assets; it accounts for depreciation and the opportunity cost of the funds tied up in the good. For housing, we estimate a hedonic model for housing based on characteristics of the structure, as well as the location, and derive an imputed rental value from this. ${ }^{14}$ All values are in Afghani.

At the district level, we include dummies for topography — plateau and mountainous areas (plains areas make up the excluded category). To control for observable and unobservable time-invariant province-level factors that could confound the results, we include province dummy variables. While this method does not control for time-varying province characteristics, it does control for factors such as instability and conflict that may present in certain provinces throughout the survey year.

\footnotetext{
${ }^{12}$ An alternative approach to account for such differences employs equivalency scales that take into account nutritional requirements based on age and, sometimes, gender when calculating per capita measures. See, for an early example, Buse and Salathe (1978). An advantage of including household composition in the specification, rather than using equivalence scales, is that this method allows the data to specify the parameterization of the scales.

${ }^{13}$ In previous versions of this work, we included quintiles of total per capita consumption in the specification to control for wealth and socio-economic status. A concern with this specification is that food consumption is one component of total consumption, thus inclusion of total consumption in any form would introduce endogeneity bias. We are grateful to a conference discussant for noting that, even more importantly, the inclusion of the consumption quintiles only allows the price effect to pick up variation within consumption quintiles and not across quintiles. In lieu of consumption, we now use multiple measures of assets to control for wealth and socio-economic status, and we treat these as fixed in the short run (i.e., not immediately linked to food consumption).

14 The estimated housing value is the log of imputed, monthly rental value based on a hedonic model of the housing structure. The log value of assets is a self-assessed valuation based on a list of 13 assets including items such as stoves, refrigerators, radios, sewing machines, and bicycles. For details of the estimation, see Islamic Republic of Afghanistan, Central Statistics Organization (2011).
} 


\section{Model Estimation}

We estimate the parameters above with both ordinary least squares (OLS) and unconditional quantile regression (UQR). Each estimator has advantages and disadvantages, which we describe below. We argue that from a policy perspective the UQR estimator has the benefit of allowing one to examine the behavioral changes at a specific location on the distribution (such as the $25^{\text {th }}$ quantile) or at a particular threshold on the distribution (such as the food poverty line) of the dependent variable.

OLS provides an estimate of the partial derivative $\left(\beta_{1-\mathrm{OLS}}\right)$ of the conditional mean of the food security-related dependent variables with respect to changes in the price of wheat flour in equation (1). $\beta_{1-\mathrm{OLS}}$ is also a consistent estimator of the partial derivative of the unconditional mean of the dependent variable. This equivalence in interpretation stems from the linearity of OLS and the law of iterated expectations. ${ }^{15}$ Thus an advantage of OLS is that the distinction between the conditional and unconditional distributions is not a concern. The marginal effects estimated by OLS are, by construction, constant over the entire conditional distribution. For those interested in knowing whether marginal effects differ at the tails of the distribution, this is a decided shortcoming of OLS.

The quantile estimator allows the partial response to vary across the conditional distribution. This flexibility is particularly relevant for policy analysis; for example, stakeholders may be interested in the impact of high food prices on those living close to subsistence levels rather than the response for the average (mean) household.

The quantile estimator estimates the conditional quantile marginal effect (CQME) or the partial derivative, as described by the following expression:

$\frac{\partial Q_{f s}(\tau \mid X)}{\partial p r i c e \text { wheat flour }}$

Following the notation of Koenker (2005), $Q_{f s}$ is the conditional quantile function of our food security-related measures and $\tau$ represents quantiles of the conditional distribution.

\footnotetext{
${ }^{15}$ The law of iterated expectations states that if $\mathrm{X}$ and $\mathrm{Y}$ are random variables, and $\mathrm{Y}$ is integrable, then the expected value of $\mathrm{Y}$ is equal to the expectation of the expected value of $\mathrm{Y}$ conditional on $\mathrm{X}$; that is, $\mathrm{E}(\mathrm{Y})=\mathrm{E}[\mathrm{E}(\mathrm{Y} \mid \mathrm{X})]$.
} 
The estimated CQME can differ at each $\tau^{\text {th }}$ quantile of the conditional distribution of the dependent variable. ${ }^{16}$ Chamberlain (1994) illustrates the usefulness of this attribute by estimating the wage premium from union participation. OLS results indicate that union participation has a positive effect on mean wages, but the quantile estimator results indicate a much larger premium to participation for those who are on the left-hand tail of the conditional distribution. Thus for low-wage earners, OLS appears to underestimate the effect of union participation, a fact that may be of relevance to social policy.

The disadvantage of the quantile estimator is that its nonlinearity means that the CQME is not equal to the unconditional quantile marginal effect (UQME). The parameter estimate from the quantile estimator measures the marginal effect evaluated at the $\tau^{\text {th }}$ quantile of the conditional, not unconditional, distribution. Equation (3) formalizes this statement.

$\frac{\partial Q_{f s}(\tau \mid X)}{\partial p r i c e \text { wheat flour }} \neq \frac{\partial Q_{f s}(\tau)}{\partial p \text { rice wheat flour }}$

This distinction between the conditional and unconditional distributions is important because policymakers may not be interested in the CQME, but rather may want to know the effect of the explanatory variable on the unconditional distribution or the unconditional quantile marginal effect (UQME). For example, policymakers are likely to be more interested in the price responsiveness of households who are at the food poverty line and not those who are at the point on the conditional distribution that corresponds to the food poverty line after conditioning on several other household characteristics.

Firpo, Fortin and Lemieux (2009b, hereafter referred to as FFL) recently proposed a new estimator, the UQR estimator, which improves on both the OLS and quantile estimators. The UQR estimator allows marginal effects to be estimated at different points on the distribution, like the quantile estimator; and also respects the law of iterated expectations, like OLS. The implication of these attributes is that the UQR estimator provides an estimate of the UQME, which we argue is a key parameter for policy decision-

\footnotetext{
${ }^{16}$ It is not always the case that the quantile estimator will necessarily provide qualitatively different information than OLS, but Koenker and Bassett (1982) show that in the presence of a heteroscedastic error distribution, the quantile estimator will typically differ from the OLS estimator.
} 
making.

The UQR estimator is based on influence functions, which were introduced by Hampel (1988) as a tool in robust estimation techniques. ${ }^{17}$ Using notation (largely) from FFL, consider some distributional statistic, $v\left(\mathrm{~F}_{\mathrm{y}}\right)$, such as the median, inter-quantile range, or any quantile. The influence function, $\operatorname{IF}\left(\mathrm{Y} ; v, \mathrm{~F}_{\mathrm{y}}\right)$, represents the influence of an individual observation on the distributional statistic, $v\left(\mathrm{~F}_{\mathrm{y}}\right)$. A key innovation of FFL is that the authors add $v\left(\mathrm{~F}_{\mathrm{y}}\right)$ to the influence function to center it; this new function is called a recentered influence function (RIF). By design then, the expectation of the RIF at the $\tau^{\text {th }}$ quantile is the value at the $\tau^{\text {th }}$ quantile (e.g., the median if $\tau=50$ ); or, more formally, $\mathrm{E}\left(\mathrm{RIF}\left(\mathrm{Y} ; v, \mathrm{~F}_{\mathrm{y}}\right)\right)=v\left(\mathrm{~F}_{\mathrm{y}}\right) . \mathrm{FFL}$ define $m_{\tau}(\mathrm{X})=\mathrm{E}\left(\mathrm{RIF}\left(\mathrm{Y} ; \tau, \mathrm{F}_{\mathrm{y}}\right) \mid \mathrm{X}\right)$ as the unconditional quantile regression model. The parameter estimates from the RIF regression provide estimates of UQME, or in our example, the marginal effect of a change in wheat flour prices on food expenditure evaluated at the food poverty line of the unconditional distribution, while controlling for the covariates in our model specification. ${ }^{18}$

With the quantile estimator, marginal effects are typically compared at fixed points on the conditional distribution. For example, Chamberlain (1994), Nguyen et al. (2007), Patrinos and Sakellariou (2006), and Stifel and Averett (2009) all examine the CQME at fixed intervals (such as the $10^{\text {th }}, 25^{\text {th }}, 50^{\text {th }}, 75^{\text {th }}$, or $90^{\text {th }}$ quantiles) on the conditional distribution. For our analysis, we similarly compare the UQME of the food security-related dependent variables at the $25^{\text {th }}, 50^{\text {th }}, 75^{\text {th }}$ quantiles of their respective distributions to examine whether the effects differ in informative ways. Table 5 displays the values of the food security measures at various points of the unconditional distributions. The observed variation in these indicators suggests that the UQME may differ for households at the bottom and top of the distributions.

We also take a slightly different approach and examine the UQME for each of the dependent variables at points on the distribution that are assumed to have specific policy or

\footnotetext{
${ }^{17}$ Robust statistics are statistics and estimators that are not heavily influenced by deviations from model assumptions, nor alternatively, heavily influenced by single observations. Influence functions provide a formal way of measuring the extent to which a particular estimator is affected by a single observation in the sample. ${ }^{18}$ FFL provide an estimation method based on transforming the dependent variable into the re-centered influence function and then using OLS estimation. FFL show that this approach yields a consistent estimator of the average marginal effect, $\mathrm{E}[\mathrm{d} \operatorname{Pr}[\mathrm{Y}>\tau \mid \mathrm{X}] / \mathrm{dX}]$, if $\operatorname{Pr}[\mathrm{Y}>\tau \mid \mathrm{X}=\mathrm{x}]$ is linear in $\mathrm{x}$. In order to estimate the standard errors, we follow FFL (2009b) and use a bootstrap estimator of the sampling variance. For the interested reader, FFL (2009a) derive the asymptotic properties of the estimator and provide the analytical standard errors.
} 
nutritional relevance. When examining per capita food expenditure, we estimate the UQME of a change in wheat flour prices at the point on the distribution that corresponds to the food poverty line. This line is a policy-relevant threshold on the expenditure distribution that is constructed to measure the minimum cost of obtaining 2,100 calories per person per day (following typical consumption patterns of the relatively poor). Similarly, we examine the UQME at points on the distribution corresponding to 2,100 calories (a conventional nutritional benchmark which is also the calorie basis for the national poverty line), and the World Food Programme food consumption score thresholds of 28 (identifying a poor diet) and 42 (identifying a marginal diet). Measuring responses at these thresholds provides information on how individuals and households on the cusp of poverty and/or malnutrition cope with food price increases.

\section{Results}

In this section, we first present and compare the results using the OLS estimator and the unconditional quantile regression estimator for quartiles $\left(25^{\text {th }}, 50^{\text {th }}\right.$, and $75^{\text {th }}$ quantiles $)$ of each dependent variable distribution. We then present and discuss estimates corresponding to the policy-relevant thresholds described above. The tables display the coefficients of interest. Full sets of results can be found in the online appendix, Tables A2-A6.

\section{OLS and unconditional quantile regression estimation}

An increase in the price of wheat flour is associated with statistically significant declines in the food security-related measures at the means of the unconditional distributions of the food security-related measures and across the distributions (Table 6).

The OLS estimates reveal a negative marginal effect of an increase in the price of wheat flour on the real value of monthly per capita food consumption; due to the nature of the OLS estimator, this coefficient represents the estimated response for all households across the distribution. Similar to the results in D'Souza and Jolliffe (2012), this reduction is approximately evenly split between a reduction in caloric intake and dietary diversity. ${ }^{19} \mathrm{We}$

\footnotetext{
19 The coefficients are larger in magnitude than those in D'Souza and Jolliffe (Forthcoming) due to differences in the specification, but the general finding that calories and diversity decline by approximately equal levels is
} 
interpret these results as a quality for quantity trade-off that households make in order to maintain energy (calorie) levels in the face of declining purchasing power. The declines in dietary diversity indicate that households changed the composition of their diets, perhaps by cutting back on more expensive, nutrient-rich foods and moving toward cheaper foods and food groups. Such changes in dietary composition can have potentially serious implications for more vulnerable groups who have high nutrient requirements, such as children at developmental stages, pregnant and lactating mothers, and the elderly.

The results across the distributions of households paint a richer picture of the impact of the price shocks. As may have been expected, richer households $\left(75^{\text {th }}\right.$ quantile), in terms of food consumption, experienced a much larger drop in the real value of food consumption; in fact, the percentage reduction for these households is over two and a half times as large as the reduction for households at the bottom quartile $\left(25^{\text {th }}\right.$ quantile $) .{ }^{20}$ At a very basic level, richer households have more to give, whereas poorer households cannot make large reductions to their food consumption because they live closer to subsistence levels. Further, richer households host more guests, eat away from home more often, and may waste more food, on average, than poorer households.

The estimates of changes in caloric intake support a similar story. Those at the bottom of the calorie distribution $\left(25^{\text {th }}\right.$ quantile) experience a very small decline in daily per capita intake, equivalent to about 175 calories or a third of a standard naan (Afghan bread). These households are living at the threshold of energy requirements (with an average daily per capita caloric intake of 2,030) and, most likely, are unable to cut back on calories without suffering serious nutritional consequences. In contrast, the percentage reduction in caloric

the same. The coefficients from the regression analysis correspond (approximately) to a one percent increase in the price of wheat flour. Converting the coefficients to percentage changes associated with a 10 percent increase in wheat flour prices suggests that there would be a corresponding $4.3 \%$ reduction in the value of food consumption and slightly less than $2 \%$ reductions in both caloric intake and dietary diversity.

${ }^{20}$ We note here the standard caution that the regression coefficients represent estimated effects from small, marginal price changes. This caution against using estimated marginal effects as a basis for simulating large, non-marginal price changes is particularly warranted in the case of quantile estimators where different estimated effects across the distribution of the dependent variable imply a changing shape of this distribution due to price changes. Variation in the estimated marginal effects at different points on the distribution can readily imply re-rankings of observations (in terms of the dependent variable) with large enough simulated changes. But this exercise would be nonsensical as one would expect that as the shape of the distribution changes due to non-marginal price changes, there would be a new set of estimated marginal effects at each of the points on the distribution. 
intake for richer households $\left(75^{\text {th }}\right.$ quantile) is over three times as large as that for poorer households.

These adjustments in caloric intake link directly to concessions in dietary quality. Households at the bottom of the dietary diversity distribution must make larger reductions in the diversity of their diets to maintain energy levels, relative to those at the top of the distribution. The richer households ( $75^{\text {th }}$ quantile) make larger percentage reductions in the quantity (calories) of food consumed than in the quality (dietary diversity) of food consumed.

These findings are consistent with the literature on the impact of high food prices on nutritional outcomes. For example, Klotz et al. (2008) argue that during times of economic crisis and when households cannot increase the amount that they spend on food, they are forced to cut back on expensive, micronutrient-rich foods to maintain their consumption of core staples. Therefore economic shocks will lead to micronutrient deficiencies before weight loss. Jensen and Miller (2008) similarly find that in the face of food price inflation, poor urban households in China substitute toward cheaper foods.

These findings are also consistent with past studies related to the impact of economics shocks on nutrition. Diagana et al. (1999) find decreases in levels of dietary diversity and changes in food consumption patterns after the 1994 devaluation of the CFA franc using data from West Africa. Martin-Prevel et al. (2000) find reductions in maternal and nutritional status following the same currency devaluation. And Block et al. (2004) find declines in maternal and child nutritional status following drought and financial crisis in Indonesia in 1997-98. See Ruel et al. (2010) for a more detailed review of the literature on the effects of economic crises on household wellbeing.

\section{Policy-relevant thresholds}

In terms of the value of food consumption and caloric intake, the marginal effects estimated at the policy-relevant cutoff by UQR are smaller than those estimated by OLS, implying that the average household is more affected by price shocks than those living near subsistence levels (Table 7). For example, OLS estimates indicate that the wheat-price elasticity of food consumption is -0.43 , but when we estimate this elasticity at the food poverty line using 
UQR, the household response is much less elastic with a value of -0.30 . Similarly for caloric intake, the average wheat-price elasticity (as estimated by OLS) is -0.18 , but when estimated at the point on the distribution corresponding to a daily intake of 2,100 calories, this estimate shrinks in magnitude to -0.12. If the policymaker is focused on how the food poor, or calorie deficient, are affected by wheat price increase, these results suggest that OLS will overestimate this effect by about $30 \%$ in the case of consumption and $38 \%$ in the case of calories. This finding is consistent with a story of market exposure, as well as the story described above that richer households have more to give in terms of the value of their food consumption and their caloric intake. We expect households living close to subsistence levels to have a lower level of market participation (e.g., more likely to be subsistence farmers) and thus be less affected by price shocks.

For dietary diversity the difference between the average elasticity and the elasticity estimated at the cutoff for a borderline diet (food consumption score $=42$ ) go in the opposite direction. In this case, the OLS estimate is -0.19 , but the UQR estimate for households with borderline diet is -0.26 , indicating a greater decline in diversity from an increase in wheat prices. The substantial decreases in dietary quality indicated by these results suggest that the micronutrient intake of some or all individuals in these households may have declined in a significant way. These findings provide useful information for policymakers as they seek to better understand the behavior of the most vulnerable households during times of high food price inflation.

\section{Extensions}

Equation (1) models changes in food security for all households at the national level; however we may expect these changes to differ based on whether a household cultivates wheat. Deaton $(1989,2000)$ draws a theoretical distinction between households that produce (and sell) their own food and those that do not. Net buyers depend on the market to meet their food needs, while net sellers produce enough food to consume and to sell on the market. Increases in food prices hurt net buyers, but benefit net sellers whose revenues increase. The NRVA data do not allow us to distinguish directly between these households, thus we use an indicator for households that report owning or operating agricultural land as a broad proxy for this distinction. While not all households that have access to agricultural 
land are net sellers of food, most net sellers of food have access to agricultural land. To incorporate this distinction into the model, we add in an interaction between the log of wheat flour prices and the dummy for agricultural households (i.e., owners or operators of agricultural land).

Overall, we find little evidence consistent with the expected result that net sellers benefited from the price increases. Using the dummy for agricultural households as a proxy for net sellers does produce some differences in the results, but none that are necessarily consistent with the hypothesis that such households weather the price increases better than those who do not own or operate agricultural land.

We find no evidence of a differential impact of the price shocks on the real value of food consumption for these two groups (Table 8$)^{21}$. In terms of the OLS results, the estimates suggest that both types of households reduce the quantity (as measured by calories) and quality (as measured by food diversity) of food consumed, but agricultural households sacrifice more in terms of calories and less in terms of quality.

In terms of the UQR results for the calorie distribution, the results are similar to the national estimates discussed above. The decline in calories from a marginal price increase is much larger in absolute value for both household types (i.e., agricultural and nonagricultural) at the upper quartile of caloric intake (relative to those at the median and lower quartiles). This difference is more pronounced at the upper quartile for the agricultural households, with the caloric decline increasing for this group. In terms of dietary diversity, the results at each quartile do differ qualitatively from the national estimates. The reduction in dietary diversity is less severe for agricultural households (relative to non-agricultural households) at the median and lower quartile. Across the quartiles for agricultural households, the variation in the responses is more tempered with no marked pattern of gradient. One potential explanation for these (non)results is that our proxy is not a useful measure of the net-buyer ratio. The survey does not allow us to measure how much of

\footnotetext{
${ }^{21}$ One might be concerned that rural-urban differences that are not captured by the agricultural household dummy or by other control variables could bias our results if certain factors, such as access to markets, are correlated with location and the price of wheat flour. We re-run the UQR model using a specification that includes a dummy for households located in rural areas. The results (not shown) are robust to this alternative specification.
} 
production is home consumed, and we assume this weakness prevents us from properly sorting the groups. ${ }^{22}$

Next we examine differences between the UQR estimates and estimates obtained using the traditional (conditional) Quantile Regression (QR) estimator. For each dependent variable the ordering of the estimates across the quartiles remains the same; however the magnitudes of the coefficients differ (Table 9). The largest differences are observed for the bottom quartiles of the food consumption and dietary diversity distributions, which could be important from a policy perspective as it relates to vulnerable populations. The QR results suggest a larger reduction in the value of food consumption for the poorest households than found using the UQR estimator. The differences are even more pronounced when looking at changes in dietary diversity. The QR estimate for the $25^{\text {th }}$ quantile is $37 \%$ smaller in magnitude than the UQR estimate, suggesting that relying solely on the former estimator could lead to an underestimate of the impact of the food price increases on these vulnerable households. These findings highlight the importance of selecting an estimator that best answers the specific policy question. If policymakers are asking questions about how foodpoor, food-insecure or calorie-deficient households react to price shocks, then the UQR estimator is best suited to provide answers. ${ }^{23}$

We also estimate the impact of the price increases on households at the $10^{\text {th }}$ and $90^{\text {th }}$ quantiles of each distribution. The patterns are consistent with and reinforce our main findings (Table 10). In line with the arguments laid out above, we find no statistically significant impact of the price increases on the caloric intake of households at the very low end of the calorie distribution - households who live at or below subsistence levels and who cannot afford to reduce energy intake.

\footnotetext{
22 Given that Afghanistan imports on average 20 percent of its wheat flour consumption and has insufficient storage and milling capacity to meet consumption needs (Haroun, 2010), it strikes us as a reasonable view that identifying a households as an agricultural household may not be too informative as to whether they are growing more wheat than they are purchasing.

${ }_{23}$ Again, this is in contrast to the QR estimator which provides answers to questions about the conditional distribution. The QR can inform on the price responsiveness of households at, say, the conditional $20^{\text {th }}$ quantile; but depending on the model specification, the conditional $20^{\text {th }}$ quantile may be quite different from the value of the $20^{\text {th }}$ quantile on the actual (unconditioned) distribution. Buchinsky (1994) provides an example where the question posed is best answered by the QR estimator, and not something like the UQR. He examines the distribution of wages in the U.S. and, using the QR estimator, provides insight into the change in within-group (i.e. conditional) wage inequality over time.
} 


\section{Conclusion}

Increases in the level and volatility of food prices over the past several years have led to a severe erosion of purchasing power in developing countries where the poor often spend the majority of their budgets on food. Increases in the price of staple foods in particular can have deleterious effects for households living at subsistence levels.

In this paper, we use the case of Afghanistan during the 2007-08 global food price crisis to examine the impact of high staple food prices on household food security. We estimate the marginal effect of increases in wheat flour prices on measures of total food consumption, caloric intake, and dietary diversity. We use the unconditional quantile regression estimator, proposed by Firpo, Fortin and Lemieux (2009b), to examine the marginal effects at the $25^{\text {th }}, 50^{\text {th }}$ and $75^{\text {th }}$ quantiles of the unconditioned distribution of each food security-related dependent variable, as well as the marginal effects associated with key policy-relevant thresholds.

The key findings of our analysis illustrate the value of distribution-sensitive analysis. We find large differences in the behavioral response of a household to wheat flour price increases based on its location on the unconditional distribution of each of our measures of food security - differences that are obscured when using OLS estimation techniques. Households at the $75^{\text {th }}$ quantile of the distribution of real food consumption experience the largest percentage decline in real food consumption for a given increase in wheat flour prices - over two and a half times larger than that of households at the $25^{\text {th }}$ quantile. Analogously, those at the $75^{\text {th }}$ quantile of the caloric intake distribution experience the largest percentage declines in caloric intake for a given increase in wheat flour prices. Households at the bottom of the caloric intake distribution make very small reductions in caloric intake due to the price increases. Such households live near subsistence levels and are forced to make adjustments to the quality of their diets in order to maintain energy levels; households at the $25^{\text {th }}$ quantile of the dietary diversity distribution make the largest reduction in dietary quality - about one and a half times larger than that of households at the $75^{\text {th }}$ quantile.

The findings have several implications. First, if policymakers focus exclusively on changes in caloric intake that result from price shocks, they may miss an important component of the big picture. While poorer households do not cut back on calories very much, it is likely that they reduce dietary quality. Such findings underscore the importance 
of micronutrient interventions such as fortification of staples and vitamin distributions during periods of high food prices.

Second, household survey consumption modules often include questions on the quantity of food items consumed or the expenditure on food items, but not on the frequencies with which the food items are consumed. Given the low cost of adding questions on the frequencies of food intake, it may be beneficial to consider augmenting household surveys, particularly for populations that are vulnerable to food insecurity. Measures of dietary diversity are useful tools when detailed food journals or anthropometric data are not available and so micronutrient and macronutrient intake cannot be measured directly. Ruel (2003) discusses some of the benefits and costs of indicators of dietary diversity. In the nutrition literature, Alexander and Thomson (1992) discuss the importance of collecting frequency data in addition to quantity intake data. They demonstrate that both the quantity of food ingested and the intake frequency are important determinants of dietinduced diseases; they argue that looking solely at quantity data could be misleading. Our findings are consistent with this view.

Finally and more broadly, examining household responses using OLS estimation may be misleading since this estimator imposes the restriction that the marginal effects are constant across the distribution. Our analysis indicates that behavioral responses of those at the bottom of several key distributions are substantially different from those at the top of the distribution. This paper demonstrates the benefits of using the unconditional quantile regression estimator to examine marginal effects at various quantiles of the unconditional distribution.

\section{References}

Alexander, C. J., \& Thomson, F. J. (1992). The threshold effect: Consequences of change in the frequency of food intake in the presence of a functional threshold. Medical Hypotheses, 39(3), 302-308. doi: Doi: 10.1016/0306-9877(92)90128-y

Block, S. A., Kiess, L., Webb, P., Kosen, S., Moench-Pfanner, R., Bloem, M. W., \& Peter Timmer, C. (2004). Macro shocks and micro outcomes: child nutrition during Indonesia's crisis. Economics \& Human Biology, 2(1), 21-44. doi: DOI: 10.1016/j.ehb.2003.12.007

Buchinsky, M. (1994). Changes in the U.S. Wage Structure 1963-1987: Application of Quantile Regression. Econometrica, 62(2), 405-458. 
Buse, R. C., \& Salathe, L. E. (1978). Adult Equivalent Scales: An Alternative Approach. American Journal of Agricultural Economics, 60(3), 460-468.

Chabot, P., \& Dorosh, P. A. (2007). Wheat markets, food aid and food security in Afghanistan. Food Policy, 32(3), 334-353. doi: DOI: 10.1016/j.foodpol.2006.07.002

Chamberlain, G. (1994). Quantile Regression, Censoring, and the Structure of Wages. In S. Christopher (Ed.), Advances in Econometrics. New York: Elsevier.

D'Souza, A., \& Jolliffe, D. (2012). Rising Food Prices and Coping Strategies: HouseholdLevel Evidence from Afghanistan. Journal of Development Studies, 48(2), 282-299.

Deaton, A. (1989). Rice Prices and Income Distribution in Thailand: A Non-Parametric Analysis. The Economic Journal, 99(395), 1-37.

Deaton, A. (2000). The Analysis of Household Surveys. Baltimore: The Johns Hopkins University Press.

Deaton, A., \& Dreze, J. (2009). Food and Nutrition in India: Facts and Interpretations. Economic and Political Weekly, XLIV(7), 42-65.

Diagana, B., Akindès, F., Savadogo, K., Reardon, T., \& Staatz, J. (1999). Effects of the CFA franc devaluation on urban food consumption in West Africa: overview and crosscountry comparisons. Food Policy, 24(5), 465-478. doi: Doi: 10.1016/s03069192(99)00060-3

Firpo, S., Fortin, N., \& Lemieux, T. (2009a). Supplement to "Unconditional Quantile Regressions": Estimation and Testing. Econometrica, 77(3), 953-973.

Firpo, S., Fortin, N., \& Lemieux, T. (2009b). Unconditional Quantile Regression. Econometrica, 77(3), 953-973.

Food and Agricultural Organization, U. N. (2008). The State of Food Insecurity in the World 2008: High food prices and food security - threats and opportunities.

Hampel, F., Ronchetti, E., Rousseeuw, P., \& Stahel, W. (1988). Robust Statistics: The Approach Based on Influence Functions. New York: Wiley

Haroun, M. (2010). Food Crisis and its Impact on Afghanistan's National Security. In S.

Ahmed \& H. G. P. Jansen (Eds.), Managing food price inflation in South Asia. Dhaka: The University Press.

Islamic Republic of Afghanistan, C. S. O. C., and the World Bank Economic Policy and Poverty Sector,. (2011). Setting the Official Poverty Line for Afghanistan. Kabul: Islamic Republic of Afghanistan, CSO.

Islamic Republic of Afghanistan, M. o. E., and the World Bank Economic Policy and Poverty Sector. (2010). Poverty Status in Afghanistan: A Profile Based on the National Risk and Vulnerability Assessment (NRVA) 2007/08. Kabul: Islamic Republic of Afghanistan, Ministry of Economy, and the World Bank Economic Policy and Poverty Sector.

Jensen, R. T., \& Miller, N. H. (2008). The impact of food price increases on caloric intake in China. Agricultural Economics, 39, 465-476. doi: 10.1111/j.1574-0862.2008.00352.x

Kish, L. (1965). Survey Sampling. New York: Wiley.

Klotz, C., de Pee, S., Thorne-Lyman, A., Kraemer, K., \& Bloem, M. W. (2008). Nutrition in the Perfect Storm: Why Micronutrient Malnutrition will be a Widespread Health Consequence of High Food Prices. Sight and Life Magazine(2).

Koenker, R. (2005). Regression Quantiles. New York: Cambridge University Press.

Koenker, R., \& Bassett, G., Jr. (1982). Robust Tests for Heteroscedasticity Based on Regression Quantiles. Econometrica, 50(1), 43-61.

Martin-Prevel, Y., Delpeuch, F., Traissac, P., Massamba, J.-P., Adoua-Oyila, G., Coudert, K., \& Treche, S. (2000). Deterioration in the nutritional status of young children and 
their mothers in Brazzaville, Congo, following the 1994 devaluation of the CFA franc Bulletin (Vol. 78, pp. 108-118): World Health Organization.

Nguyen, B. T., Albrecht, J. W., Vroman, S. B., \& Westbrook, M. D. (2007). A quantile regression decomposition of urban-rural inequality in Vietnam. Journal of Development Economics, 83(2), 466-490. doi: DOI: 10.1016/j.jdeveco.2006.04.006

Patrinos, H. A., \& Sakellariou, C. (2006). Economic volatility and returns to education in Venezuela: 1992-2002. Applied Economics, 38(17), 1991 - 2005.

Ruel, M. T. (2003). Operationalizing Dietary Diversity: A Review of Measurement Issues and Research Priorities. The Journal of Nutrition, 133(11), 3911S-3926S.

Ruel, M. T., Garrett, J. L., Hawkes, C., \& Cohen, M. J. (2010). The Food, Fuel, and Financial Crises Affect the Urban and Rural Poor Disproportionately: A Review of the Evidence. The Journal of Nutrition, 140(1), 170S-176S. doi: 10.3945/jn.109.110791

Stifel, D. C., \& Averett, S. L. (2009). Childhood overweight in the United States: A quantile regression approach. Economics \& Human Biology, 7(3), 387-397. doi: DOI: 10.1016/j.ehb.2009.05.005

UNICEF. (2009). Tracking Progress on Child and Maternal Nutrition: a survival and development priority

Weismann, D., Basssett, L., Benson, T., \& Hoddinott, J. (2009). Validation of the World Food Programme's Food Consumption Score and Alternative Indicators of Household Food Security Discussion Paper IFPRI. 
Figure 1: Retail wheat flour prices, 2005-2010

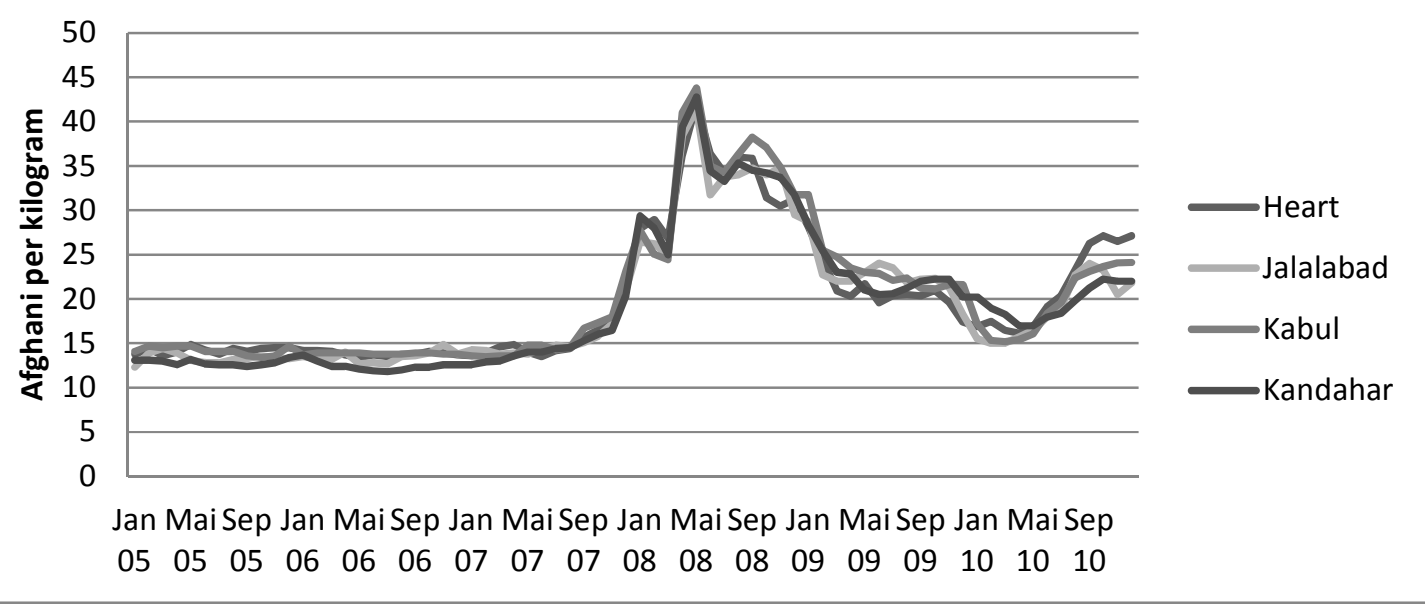


Table 1. Population means

\begin{tabular}{|c|c|c|c|}
\hline & National & $\begin{array}{c}\text { Agricultural } \\
\text { Households }^{\text {a }}\end{array}$ & $\begin{array}{c}\text { Nonagricultural } \\
\text { Households }^{\text {a }}\end{array}$ \\
\hline \multirow{2}{*}{$\begin{array}{l}\text { Nominal value of per capita monthly total } \\
\text { consumption (Afghani) }\end{array}$} & 1926 & 1752 & 2159 \\
\hline & (1158) & (934) & (1371) \\
\hline \multirow{2}{*}{$\begin{array}{l}\text { Nominal value of per capita monthly food } \\
\text { consumption (Afghani) }\end{array}$} & 1158 & 1134 & 1189 \\
\hline & (583) & (528) & (648) \\
\hline \multirow{2}{*}{ Per capita daily caloric intake (kilocalories) } & 2601 & 2587 & 2619 \\
\hline & (974) & (977) & (969) \\
\hline \multirow{2}{*}{ Food consumption score } & 60.95 & 61.59 & 60.07 \\
\hline & (20.03) & (19.48) & (20.71) \\
\hline \multirow{2}{*}{ Age of household head } & 44.87 & 45.37 & 44.19 \\
\hline & (13.78) & (13.68) & (13.89) \\
\hline \multirow{2}{*}{ Number of males } & 2.09 & 2.19 & 1.96 \\
\hline & $(1.30)$ & $(1.33)$ & $(1.25)$ \\
\hline \multirow{2}{*}{ Number of females } & 2.01 & 2.09 & 1.89 \\
\hline & (1.19) & $(1.22)$ & $(1.13)$ \\
\hline \multirow{2}{*}{ Number of children under 16} & 4.51 & 4.75 & 4.18 \\
\hline & (2.39) & $(2.46)$ & $(2.26)$ \\
\hline Dummy for married household heads & 0.95 & 0.95 & 0.94 \\
\hline Dummy for literate household heads & 0.32 & 0.30 & 0.34 \\
\hline Dummy for plateau areas & 0.22 & 0.27 & 0.16 \\
\hline Dummy for mountainous areas & 0.39 & 0.49 & 0.27 \\
\hline Total observations & 20,491 & 11,633 & 8,858 \\
\hline Percentage of full sample & 100.00 & 0.57 & 0.43 \\
\hline
\end{tabular}

Note: Estimated population weighted means. Standard deviations in parentheses. Prices in Afghani per kilogram or liter (kerosene). ${ }^{a}$ Statistical tests of differences in means (corrected for complex sample design) between prices faced by Agricultural and Nonagricultural Households (based on location) show significant differences at a 5\% level of significance for all estimated means. Source: NRVA 2007/08 
Table 2. Average prices of key commodities

\begin{tabular}{|l|c|c|c|}
\hline \hline & National & $\begin{array}{c}\text { Agricultural } \\
\text { Households }^{\text {a }}\end{array}$ & $\begin{array}{c}\text { Nonagricultural } \\
\text { Households }^{\text {a }}\end{array}$ \\
\cline { 2 - 4 } & 28.45 & 29.01 & 28.45 \\
\hline Price of wheat flour & $(8.15)$ & $(8.35)$ & $(8.15)$ \\
\hline Price of vegetable oil & 81.16 & 82.39 & 81.16 \\
\hline Price of rice & $(6.88)$ & $(6.97)$ & $(6.88)$ \\
\hline & 42.77 & 43.25 & 42.77 \\
\hline Price of lamb & $(14.93)$ & $(15.07)$ & $(14.93)$ \\
\hline & 184.44 & 183.01 & 184.44 \\
\hline Price of milk & $(11.97)$ & $(12.38)$ & $(11.97)$ \\
\hline & 26.94 & 26.57 & 26.94 \\
\hline Price of kerosene & $(23.91)$ & $(24.08)$ & $(23.91)$ \\
\hline & 48.12 & 48.80 & 48.12 \\
\hline
\end{tabular}

Note: Estimated population weighted means. Standard deviations in parentheses.

Prices in Afghani per kilogram or liter (kerosene). ${ }^{\text {a }}$ Statistical tests of differences in means (corrected for complex sample design) between prices faced by Agricultural and Nonagricultural Households (based on location) show significant differences at a $5 \%$ level of significance for all estimated means; the price of lamb is the exception. Source: NRVA 2007/08 
Table 3: Average prices by quarter

\begin{tabular}{|l|c|c|c|c|}
\hline \hline & $\begin{array}{c}\text { Quarter 1 } \\
\text { (Fall) }\end{array}$ & $\begin{array}{c}\text { Quarter 2 } \\
\text { (Winter) }\end{array}$ & $\begin{array}{c}\text { Quarter 3 } \\
\text { (Spring) }\end{array}$ & $\begin{array}{c}\text { Quarter 4 } \\
\text { (Summer) }\end{array}$ \\
\hline & \multicolumn{4}{|c|}{ Full Sample } \\
\hline Price of domestic wheat flour & 18.09 & 23.51 & 34.19 & 36.51 \\
\hline Price of vegetable oil & 64.81 & 76.93 & 88.90 & 91.70 \\
\hline Price of domestic rice & 33.93 & 33.99 & 46.16 & 55.29 \\
\hline Price of lamb & 182.34 & 186.20 & 189.28 & 180.27 \\
\hline Price of milk & 23.44 & 25.66 & 27.23 & 30.75 \\
\hline Price of kerosene & 43.15 & 45.78 & 46.83 & 55.48 \\
\hline
\end{tabular}

Note: Estimated population weighted means. Prices in Afghani per kilogram or liter (kerosene).

Source: NRVA 2007/08

Table 4. Population statistics by quarter

\begin{tabular}{|l|c|c|c|c|}
\hline \hline & $\begin{array}{c}\text { Quarter 1 } \\
\text { (Fall) }\end{array}$ & $\begin{array}{c}\text { Quarter 2 } \\
\text { (Winter) }\end{array}$ & $\begin{array}{c}\text { Quarter 3 } \\
\text { (Spring) }\end{array}$ & $\begin{array}{l}\text { Quarter 4 } \\
\text { (Summer) }\end{array}$ \\
\hline & \multicolumn{4}{|c|}{ Full Sample } \\
\hline Nominal value of monthly total consumption & 2017.79 & 1902.86 & 1876.92 & 1914.64 \\
\hline Real value of monthly total consumption & 2022.00 & 1718.27 & 1519.12 & 1477.56 \\
\hline Nominal value of monthly food consumption & 1196.98 & 1123.25 & 1129.01 & 1182.97 \\
\hline Real value of monthly food consumption & 1201.19 & 961.26 & 789.41 & 797.60 \\
\hline Daily caloric intake & 2884.92 & 2725.03 & 2445.83 & 2387.33 \\
\hline Food consumption score & 67.88 & 61.28 & 57.86 & 57.69 \\
\hline $\begin{array}{l}\text { Note: Estimated population w eighted means. All values in per capita terms, except the food } \\
\text { consumption score that is calculated for the household. Real values in Afghani reflect adjustments } \\
\text { for spatial and temporal price differences, covering 13 months of field work. Caloric intake in } \\
\text { kilocalories. Source: NRVA 2007/08 }\end{array}$ \\
\hline
\end{tabular}


Table 5. Food security measures across the distribution

\begin{tabular}{|l|c|c|c|c|}
\hline \hline National sample & Mean & 25 th & 50 th & 75 th \\
\hline $\begin{array}{l}\text { Real value of per capita monthly } \\
\text { food consumption }\end{array}$ & 929 & 612 & 810 & 1101 \\
\hline $\begin{array}{l}\text { Daily per capita caloric intake } \\
\text { Food consumption score }\end{array}$ & 2601 & 2030 & 2441 & 3006 \\
\hline Agricultural hous eholds & Mean & 25 th & 50 th & 75 th \\
\hline $\begin{array}{l}\text { Real value of per capita monthly } \\
\text { food consumption }\end{array}$ & 911.29 & 606.95 & 801.34 & 1088.28 \\
\hline Daily per capita caloric intake & 2586.81 & 2026.04 & 2419.25 & 2964.53 \\
\hline Food consumption score & 61.59 & 48.00 & 62.00 & 74.00 \\
\hline Nonagricultural house holds & Mean & 25 th & 50 th & 75 th \\
\hline $\begin{array}{l}\text { Real value of per capita monthly } \\
\text { food consumption }\end{array}$ & 951.86 & 619.16 & 821.26 & 1121.48 \\
\hline Daily per capita caloric intake & 2619.47 & 2033.54 & 2470.99 & 3044.94 \\
\hline Food consumption score & 60.07 & 44.00 & 59.50 & 75.00 \\
\hline
\end{tabular}

See Table 4 notes.

Table 6. Effects of wheat flour price increases on food security

\begin{tabular}{|c|c|c|c|c|}
\hline & \multirow[t]{2}{*}{ OLS } & \multicolumn{3}{|c|}{ Unconditional Quantile Regression } \\
\hline & & 25th quantile & 50th quantile & 75th quantile \\
\hline \multirow{2}{*}{$\begin{array}{l}\text { Log Real Value of Monthly Per Capita } \\
\text { Food Consumption }\end{array}$} & $-0.425 * * *$ & $-0.242 * * *$ & $-0.433^{* * *}$ & $-0.619 * * *$ \\
\hline & [0.0364] & [0.0437] & [0.0447] & {$[0.0571]$} \\
\hline \multirow{2}{*}{ Log Daily Per Capita Calorie Intake } & $-0.184^{* * *}$ & $-0.0866^{* * *}$ & $-0.187^{* * *}$ & $-0.279 * * *$ \\
\hline & [0.0244] & [0.0290] & [0.0268] & {$[0.0340]$} \\
\hline \multirow{2}{*}{ Log Food Consumption Score } & $-0.189 * * *$ & $-0.246 * * *$ & $-0.173 * * *$ & $-0.158 * * *$ \\
\hline & {$[0.0270]$} & {$[0.0508]$} & {$[0.0305]$} & {$[0.0319]$} \\
\hline
\end{tabular}

Note: Coefficients and standard errors are from separate, population weighted regressions with dependent variable listed in the first column. Total observations: 20,483. OLS standard errors are corrected for clustering and stratification, UQR standard errors are clustered bootstrap (with replacement) estimates. *, **, and $* * *$ denote significance at $10 \%, 5 \%$, and $1 \%$, respectively. 
Table 7. Marginal effects at policy-relevant cutoffs

\begin{tabular}{|l|c|c|}
\hline \hline & OLS & UQR \\
\hline & Mean & $\begin{array}{c}\text { Policy-relevant } \\
\text { cutoff }\end{array}$ \\
\hline Log Real Value of Monthly Per Capita Food Consumption & $-0.425^{* * *}$ & $-0.298^{* * *}$ \\
\hline Cutoff: Value $=687.13$ & {$[0.0364]$} & {$[0.0437]$} \\
\hline Log Daily Per Capita Calorie Intake & $-0.184^{* * *}$ & $-0.115^{* * *}$ \\
\hline Cutoff: Intake $=2,100$ & {$[0.0244]$} & {$[0.0279]$} \\
\hline Log Food Consumption Score & & \\
\hline Mean & $-0.189^{* * *}$ & \\
\hline & {$[0.0270]$} & \\
\hline Poor Diet Cutoff: Score $=28$ & & $-0.163^{* * *}$ \\
\hline & & {$[0.0565]$} \\
\hline Borderline Diet Cutoff: Score $=42$ & & $-0.256^{* * *}$ \\
\hline & & {$[0.0518]$} \\
\hline
\end{tabular}

See Table 6 notes. Below the dependent variable, we list the policy-relevant cutoff at which the marginal effect is evaluated using UQR. 
Table 8. Coefficients of interest at the sub-national level

\begin{tabular}{|c|c|c|c|c|}
\hline & \multirow[t]{2}{*}{ OLS } & \multicolumn{3}{|c|}{ Unconditional Quantile Regression } \\
\hline & & 25th quantile & 50th quantile & 75th quantile \\
\hline & \multicolumn{4}{|c|}{ Log Real Value of Monthly Per Capita Food Consumption } \\
\hline \multirow{2}{*}{ Log Price of Wheat Flour } & $-0.437^{* * *}$ & $-0.220 * * *$ & $-0.416^{* * *}$ & $-0.615^{* * *}$ \\
\hline & {$[0.0401]$} & [0.0460] & [0.0540] & {$[0.0608]$} \\
\hline \multirow{2}{*}{$\begin{array}{c}\text { Log Price of Wheat Flour X } \\
\text { Agricultural Household }\end{array}$} & 0.0196 & -0.0355 & -0.0275 & -0.0072 \\
\hline & [0.0288] & [0.0349] & [0.0336] & [0.0410] \\
\hline \multirow[t]{2}{*}{$\begin{array}{l}\text { P-value of F-Statistic of Joint } \\
\text { Significance }\end{array}$} & 0.00 & 0.00 & 0.00 & 0.00 \\
\hline & \multicolumn{4}{|c|}{ Log Daily Calorie Per Capita Intake } \\
\hline \multirow{2}{*}{ Log Price of Wheat Flour } & $-0.138 * * *$ & $-0.0641^{* *}$ & $-0.136^{* * *}$ & $-0.237^{* * *}$ \\
\hline & [0.0263] & [0.0298] & [0.0285] & [0.0356] \\
\hline \multirow{2}{*}{$\begin{array}{l}\text { Log Price of Wheat Flour X } \\
\text { Agricultural Household }\end{array}$} & $-0.0750 * * *$ & -0.037 & $-0.0837 * * *$ & $-0.0700 * * *$ \\
\hline & [0.0203] & [0.0231] & [0.0206] & [0.0267] \\
\hline \multirow[t]{2}{*}{$\begin{array}{l}\text { P-value of F-Statistic of Joint } \\
\text { Significance } \\
\end{array}$} & 0.00 & 0.01 & 0.00 & 0.00 \\
\hline & \multicolumn{4}{|c|}{ Log Food Consumption Score } \\
\hline \multirow{2}{*}{ Log Price of Wheat Flour } & $-0.229 * * *$ & $-0.317^{* * *}$ & $-0.201^{* * *}$ & $-0.156^{* * *}$ \\
\hline & {$[0.0300]$} & [0.0551] & {$[0.0316]$} & {$[0.0341]$} \\
\hline \multirow{2}{*}{$\begin{array}{c}\text { Log Price of Wheat Flour X } \\
\text { Agricultural Household }\end{array}$} & $0.0665^{* * *}$ & $0.117^{* * *}$ & $0.0459 * *$ & -0.00321 \\
\hline & {$[0.0195]$} & [0.0368] & [0.0215] & {$[0.0240]$} \\
\hline $\begin{array}{l}\text { P-value of F-Statistic of Joint } \\
\text { Significance }\end{array}$ & 0.00 & 0.00 & 0.00 & 0.00 \\
\hline
\end{tabular}

Note: Each set of coefficients and standard errors are from separate, population weighted regression, with the dependent variable listed above the estimates. Total observations: 20,483. OLS standard errors are corrected for clustering and stratification, UQR standard errors are clustered bootstrap (with replacement) estimates. $*, * *$, and $* * *$ denote significance at $10 \%$, $5 \%$, and $1 \%$, respectively. 
Table 9. Unconditional and conditional quantile regression estimates

\begin{tabular}{|c|c|c|c|c|c|c|}
\hline & \multicolumn{3}{|c|}{ UQR } & \multicolumn{3}{|c|}{ QR } \\
\hline & $\begin{array}{c}25 \text { th } \\
\text { quantile }\end{array}$ & $\begin{array}{c}\text { 50th } \\
\text { quantile }\end{array}$ & $\begin{array}{c}75 \text { th } \\
\text { quantile }\end{array}$ & $\begin{array}{c}25 \text { th } \\
\text { quantile }\end{array}$ & $\begin{array}{c}\text { 50th } \\
\text { quantile }\end{array}$ & $\begin{array}{c}75 \text { th } \\
\text { quantile }\end{array}$ \\
\hline $\begin{array}{l}\text { Log Real Value of Monthly Per } \\
\text { Capita Food Consumption }\end{array}$ & [0.0437] & [0.0447] & [0.0571] & [0.0259] & [0.0227] & [0.0263] \\
\hline Log Daily Per Capita Calorie Intake & $-0.0866 * * *$ & $-0.187^{* * *}$ & $-0.279 * * *$ & $-0.0933^{* * *}$ & $-0.169 * * *$ & $-0.262 * * *$ \\
\hline Log Food Consumption Score & {$[0.0508]$} & {$[0.0305]$} & {$[0.0319]$} & {$[0.0227]$} & {$[0.0163]$} & {$[0.0159]$} \\
\hline
\end{tabular}

See Table 6 notes. QR represents unconditional quantile regression estimation.

Table 10. UQR results for 10th and 90th quantiles

\begin{tabular}{l|c|c|}
\hline \hline & 10th quantile & 90th quantile \\
\cline { 2 - 3 } Log Real Value of Monthly Per Capita Food Consumption & $-0.129^{* *}$ & $-0.725^{* * *}$ \\
\cline { 2 - 3 } & {$[0.0521]$} & {$[0.0762]$} \\
\hline Log Daily Per Capita Calorie Intake & 0.00402 & $-0.382^{* * *}$ \\
\hline \multirow{2}{*}{ Log Food Consumption Score } & {$[0.0444]$} & {$[0.0486]$} \\
\hline & $-0.248^{* * *}$ & $-0.183^{* * *}$ \\
\hline
\end{tabular}

See Notes for Table 6 . 
Table A1. Key indicators across quarters

\begin{tabular}{|c|c|c|c|c|c|}
\hline & $\begin{array}{c}\text { Quarter } 1 \\
\text { (Fall) }\end{array}$ & $\begin{array}{c}\text { Quarter 2 } \\
\text { (Winter) }\end{array}$ & $\begin{array}{c}\text { Quarter 3 } \\
\text { (Spring) }\end{array}$ & $\begin{array}{l}\text { Quarter } 4 \\
\text { (Summer) }\end{array}$ & All \\
\hline \multicolumn{6}{|l|}{ Demographic Indicators } \\
\hline Average household size* & 7.4 & 7.5 & 7.1 & 7.2 & 7.3 \\
\hline Average age (years) & 20.6 & 20.4 & 20.7 & 20.5 & 20.6 \\
\hline Household members \%, age <15) & 47.9 & 48.7 & 48.4 & 48.7 & 48.5 \\
\hline Age dependency ratio & 131.6 & 134.2 & 133.6 & 134.0 & 133.4 \\
\hline \multicolumn{6}{|l|}{ Education and Health Indictors } \\
\hline Full Immunization (\%, age $12-23$ months)* & 33.0 & 41.1 & 34.8 & 37.6 & 36.7 \\
\hline Literate household head $(\%)^{*}$ & 34.4 & 28.8 & 28.4 & 29.5 & 30.1 \\
\hline Ever attended school $(\%, \text { age }>18)^{*}$ & 21.7 & 21.3 & 18.9 & 21.6 & 20.9 \\
\hline Education level of persons (age >18) & 2.0 & 1.9 & 1.6 & 1.9 & 1.9 \\
\hline \multicolumn{6}{|c|}{ Access to Services and Infrastructure Indicators } \\
\hline Safe drinking water $(\% \mathrm{hh})^{*}$ & 30.4 & 27.7 & 24.2 & 25.3 & 26.8 \\
\hline Sanitary toilet (\% hh) & 5.9 & 5.6 & 4.5 & 4.0 & 4.9 \\
\hline Electricity (\% hh) & 40.9 & 42.2 & 41.5 & 39.8 & 41.1 \\
\hline
\end{tabular}


Table A2. National results using the OLS estimator

\begin{tabular}{|c|c|c|c|}
\hline & $\begin{array}{l}\text { Log Real Value of } \\
\text { Monthly Food } \\
\text { Consumption }\end{array}$ & $\begin{array}{l}\text { Log Daily Calorie } \\
\text { Intake Per Capita }\end{array}$ & $\begin{array}{c}\text { Log Food } \\
\text { Consumption Score }\end{array}$ \\
\hline \multirow[t]{2}{*}{ Log Wheat Flour Price } & $-0.425^{* * *}$ & $-0.184^{* * *}$ & $-0.189 * * *$ \\
\hline & {$[0.0364]$} & {$[0.0244]$} & {$[0.0270]$} \\
\hline \multirow[t]{2}{*}{ Agricultural Household } & $0.0351^{* * *}$ & $0.0302^{* * *}$ & $0.0310^{* * *}$ \\
\hline & [0.0100] & [0.00713] & {$[0.00727]$} \\
\hline \multirow{2}{*}{$\begin{array}{c}\text { Log Real Value Monthly } \\
\text { Housing Per Capita }\end{array}$} & $0.0366^{* * *}$ & -0.00489 & $0.0381 * * *$ \\
\hline & [0.00684] & [0.00444] & [0.00479] \\
\hline \multirow{2}{*}{$\begin{array}{c}\text { Log Real Value Monthly } \\
\text { Durables Per Capita }\end{array}$} & $0.0996 * * *$ & $0.0375^{* * *}$ & $0.0571 * * *$ \\
\hline & [0.00444] & [0.00332] & {$[0.00303]$} \\
\hline \multirow{2}{*}{$\begin{array}{l}\text { Log Real Value Livestock } \\
\text { Per Capita }\end{array}$} & $0.0133^{* * *}$ & $0.00670^{* * *}$ & $0.0166^{* * *}$ \\
\hline & [0.00128] & [0.000932] & [0.000999] \\
\hline \multirow[t]{2}{*}{ Log Kerosene Price } & $0.233^{* * *}$ & $0.179 * * *$ & -0.0286 \\
\hline & {$[0.0644]$} & {$[0.0461]$} & {$[0.0477]$} \\
\hline \multirow[t]{2}{*}{ Log Vegetable Oil Price } & $-0.140 * *$ & 0.0136 & -0.0329 \\
\hline & [0.0598] & [0.0443] & [0.0442] \\
\hline \multirow[t]{2}{*}{ Log Local Rice Price } & -0.0059 & $-0.109 * * *$ & $0.0734^{* * *}$ \\
\hline & [0.0398] & [0.0264] & {$[0.0263]$} \\
\hline \multirow[t]{2}{*}{ Log Lamb Price } & -0.128 & -0.0488 & -0.0199 \\
\hline & [0.0903] & [0.0629] & {$[0.0644]$} \\
\hline \multirow[t]{2}{*}{ Log Milk Price } & $-0.140 * * *$ & $-0.143^{* * *}$ & $-0.103^{* * *}$ \\
\hline & {$[0.0376]$} & {$[0.0280]$} & {$[0.0268]$} \\
\hline \multirow[t]{2}{*}{ Head Age } & 0.00173 & 0.0284 & 0.024 \\
\hline & {$[0.0264]$} & [0.0213] & {$[0.0200]$} \\
\hline \multirow[t]{2}{*}{ Head Married } & 0.00754 & $-0.0323 * * *$ & $0.0621^{* * *}$ \\
\hline & {$[0.0144]$} & {$[0.0106]$} & [0.0101] \\
\hline \multirow[t]{2}{*}{ Head Literate } & $-0.0371 * * *$ & -0.000189 & $-0.0453^{* * *}$ \\
\hline & [0.00775] & [0.00610] & [0.00572] \\
\hline \multirow[t]{2}{*}{ Number Men } & 0.00194 & -0.004 & $0.0198^{* * *}$ \\
\hline & [0.00382] & [0.00303] & [0.00294] \\
\hline \multirow[t]{2}{*}{ Number Women } & -0.00192 & $-0.00502 *$ & $0.0167 * * *$ \\
\hline & [0.00353] & [0.00275] & [0.00256] \\
\hline \multirow[t]{2}{*}{ Number Children } & $-0.0208^{* * *}$ & $-0.0212 * * *$ & $0.0128 * * *$ \\
\hline & [0.00177] & {$[0.00144]$} & [0.00127] \\
\hline \multirow[t]{2}{*}{ Plateau } & 0.00367 & $5.49 \mathrm{E}-06$ & -0.00466 \\
\hline & {$[0.0210]$} & {$[0.0141]$} & [0.0153] \\
\hline \multirow[t]{2}{*}{ Mountainous } & -0.00373 & 0.00126 & -0.0115 \\
\hline & [0.0196] & [0.0141] & [0.0139] \\
\hline Observations & 20,483 & 20,483 & 20,483 \\
\hline R-squared & 0.353 & 0.25 & 0.392 \\
\hline
\end{tabular}

Note: Each column represents a separate regression with population weighted estimates. Robust standard errors -in brackets- are clustered by stratum and adjusted for survey design. Real values reflect adjustments for spatial and temporal price differences. Plains is excluded category. $*$, **, and $* * *$ denote significance at $10 \%, 5 \%$, and $1 \%$, respectively. 
Table A2. National results using the OLS estimator

\begin{tabular}{|c|c|c|c|}
\hline & $\begin{array}{c}\text { Log Real Value of } \\
\text { Monthly Food } \\
\text { Consumption }\end{array}$ & $\begin{array}{l}\text { Log Daily Calorie } \\
\text { Intake Per Capita }\end{array}$ & $\begin{array}{c}\text { Log Food } \\
\text { Consumption Score }\end{array}$ \\
\hline \multirow[t]{2}{*}{ Log Wheat Flour Price } & $-0.425^{* * *}$ & $-0.184^{* * *}$ & $-0.189 * * *$ \\
\hline & {$[0.0364]$} & {$[0.0244]$} & {$[0.0270]$} \\
\hline \multirow[t]{2}{*}{ Agricultural Household } & $0.0351 * * *$ & $0.0302 * * *$ & $0.0310 * * *$ \\
\hline & {$[0.0100]$} & {$[0.00713]$} & [0.00727] \\
\hline \multirow{2}{*}{$\begin{array}{c}\text { Log Real Value Monthly } \\
\text { Housing Per Capita }\end{array}$} & $0.0366^{* * *}$ & -0.00489 & $0.0381 * * *$ \\
\hline & {$[0.00684]$} & [0.00444] & [0.00479] \\
\hline \multirow{2}{*}{$\begin{array}{c}\text { Log Real Value Monthly } \\
\text { Durables Per Capita }\end{array}$} & $0.0996 * * *$ & $0.0375 * * *$ & $0.0571 * * *$ \\
\hline & [0.00444] & [0.00332] & [0.00303] \\
\hline \multirow{2}{*}{$\begin{array}{l}\text { Log Real Value Livestock } \\
\text { Per Capita }\end{array}$} & $0.0133^{* * *}$ & $0.00670^{* * *}$ & $0.0166^{* * *}$ \\
\hline & [0.00128] & [0.000932] & [0.000999] \\
\hline \multirow[t]{2}{*}{ Log Kerosene Price } & $0.233 * * *$ & $0.179 * * *$ & -0.0286 \\
\hline & {$[0.0644]$} & {$[0.0461]$} & [0.0477] \\
\hline \multirow[t]{2}{*}{ Log Vegetable Oil Price } & $-0.140 * *$ & 0.0136 & -0.0329 \\
\hline & [0.0598] & [0.0443] & [0.0442] \\
\hline \multirow[t]{2}{*}{ Log Local Rice Price } & -0.0059 & $-0.109 * * *$ & $0.0734^{* * *}$ \\
\hline & [0.0398] & {$[0.0264]$} & {$[0.0263]$} \\
\hline \multirow[t]{2}{*}{ Log Lamb Price } & -0.128 & -0.0488 & -0.0199 \\
\hline & [0.0903] & [0.0629] & {$[0.0644]$} \\
\hline \multirow[t]{2}{*}{ Log Milk Price } & $-0.140 * * *$ & $-0.143^{* * *}$ & $-0.103 * * *$ \\
\hline & {$[0.0376]$} & {$[0.0280]$} & {$[0.0268]$} \\
\hline \multirow[t]{2}{*}{ Head Age } & 0.00173 & 0.0284 & 0.024 \\
\hline & [0.0264] & [0.0213] & [0.0200] \\
\hline \multirow[t]{2}{*}{ Head Married } & 0.00754 & $-0.0323 * * *$ & $0.0621 * * *$ \\
\hline & [0.0144] & [0.0106] & [0.0101] \\
\hline \multirow[t]{2}{*}{ Head Literate } & $-0.0371^{* * *}$ & -0.000189 & $-0.0453^{* * *}$ \\
\hline & {$[0.00775]$} & [0.00610] & [0.00572] \\
\hline \multirow[t]{2}{*}{ Number Men } & 0.00194 & -0.004 & $0.0198 * * *$ \\
\hline & [0.00382] & [0.00303] & [0.00294] \\
\hline \multirow[t]{2}{*}{ Number Women } & -0.00192 & $-0.00502^{*}$ & $0.0167^{* * *}$ \\
\hline & [0.00353] & [0.00275] & {$[0.00256]$} \\
\hline \multirow[t]{2}{*}{ Number Children } & $-0.0208 * * *$ & $-0.0212 * * *$ & $0.0128 * * *$ \\
\hline & [0.00177] & [0.00144] & [0.00127] \\
\hline \multirow[t]{2}{*}{ Plateau } & 0.00367 & $5.49 \mathrm{E}-06$ & -0.00466 \\
\hline & [0.0210] & [0.0141] & [0.0153] \\
\hline \multirow[t]{2}{*}{ Mountainous } & -0.00373 & 0.00126 & -0.0115 \\
\hline & [0.0196] & [0.0141] & [0.0139] \\
\hline Observations & 20,483 & 20,483 & 20,483 \\
\hline R-squared & 0.353 & 0.25 & 0.392 \\
\hline \multicolumn{4}{|c|}{$\begin{array}{l}\text { Note: Each column represents a separate regression with population weighted estimates. Robust } \\
\text { standard errors -in brackets- are clustered by stratum and adjusted for survey design. Real } \\
\text { values reflect adjustments for spatial and temporal price differences. Plains is excluded category. } \\
*, * * \text {, and } * * * \text { denote significance at } 10 \%, 5 \% \text {, and } 1 \% \text {, respectively. }\end{array}$} \\
\hline
\end{tabular}


Table A3. National results using the unconditional quantile regression

\begin{tabular}{|c|c|c|c|}
\hline & \multicolumn{3}{|c|}{ Log Real Value of Monthly Food Consumption } \\
\hline & 25th & 50th & 75th \\
\hline \multirow[t]{2}{*}{ Log Wheat Flour Price } & $-0.242 * * *$ & $-0.433^{* * *}$ & $-0.619 * * *$ \\
\hline & [0.0437] & [0.0447] & [0.0571] \\
\hline \multirow[t]{2}{*}{ Agricultural Household } & $0.0382^{* * *}$ & $0.0321 * * *$ & $0.0407 * * *$ \\
\hline & {$[0.0126]$} & {$[0.0117]$} & {$[0.0138]$} \\
\hline \multirow{2}{*}{$\begin{array}{l}\text { Log Real Value Monthly } \\
\text { Housing Per Capita }\end{array}$} & $0.0210^{* *}$ & $0.0396 * * *$ & $0.0410 * * *$ \\
\hline & [0.00854] & [0.00774] & [0.00910] \\
\hline \multirow{2}{*}{$\begin{array}{l}\text { Log Real Value Monthly } \\
\text { Durables Per Capita }\end{array}$} & $0.0813^{* * *}$ & $0.0807^{* * *}$ & $0.107^{* * *}$ \\
\hline & {$[0.00568]$} & {$[0.00518]$} & [0.00733] \\
\hline \multirow{2}{*}{$\begin{array}{l}\text { Log Real Value Livestock } \\
\text { Per Capita }\end{array}$} & $0.0117^{* * *}$ & $0.0135^{* * *}$ & $0.0115^{* * *}$ \\
\hline & {$[0.00154]$} & {$[0.00147]$} & [0.00209] \\
\hline \multirow[t]{2}{*}{ Log Kerosene Price } & $0.215^{* *}$ & $0.141^{*}$ & $0.272^{* * *}$ \\
\hline & {$[0.0839]$} & {$[0.0727]$} & {$[0.0930]$} \\
\hline \multirow[t]{2}{*}{ Log Vegetable Oil Price } & -0.0755 & -0.0717 & -0.119 \\
\hline & {$[0.0621]$} & [0.0689] & {$[0.0900]$} \\
\hline \multirow[t]{2}{*}{ Log Local Rice Price } & -0.0615 & -0.00552 & 0.0283 \\
\hline & {$[0.0562]$} & {$[0.0476]$} & {$[0.0573]$} \\
\hline \multirow[t]{2}{*}{ Log Lamb Price } & -0.141 & $-0.200 *$ & $-0.258^{*}$ \\
\hline & {$[0.107]$} & {$[0.109]$} & {$[0.132]$} \\
\hline \multirow[t]{2}{*}{ Log Milk Price } & $-0.108^{* *}$ & $-0.0809 *$ & $-0.173^{* * *}$ \\
\hline & {$[0.0421]$} & {$[0.0431]$} & {$[0.0553]$} \\
\hline \multirow[t]{2}{*}{ Head Age } & 0.0192 & 0.00517 & -0.00127 \\
\hline & [0.0361] & [0.0342] & [0.0411] \\
\hline \multirow[t]{2}{*}{ Head Married } & $0.0461^{* *}$ & 0.024 & -0.00441 \\
\hline & {$[0.0189]$} & {$[0.0181]$} & {$[0.0223]$} \\
\hline \multirow[t]{2}{*}{ Head Literate } & $-0.0245^{* *}$ & $-0.0349 * * *$ & $-0.0434 * * *$ \\
\hline & [0.00973] & {$[0.00997]$} & {$[0.0128]$} \\
\hline \multirow[t]{2}{*}{ Number Men } & -0.00244 & $0.00781^{*}$ & 0.00366 \\
\hline & [0.00467] & {$[0.00467]$} & [0.00599] \\
\hline \multirow[t]{2}{*}{ Number Women } & 0.00194 & -0.00318 & 0.00264 \\
\hline & {$[0.00448]$} & {$[0.00430]$} & [0.00539] \\
\hline \multirow[t]{2}{*}{ Number Children } & $-0.0150 * * *$ & $-0.0182 * * *$ & $-0.0236^{* * *}$ \\
\hline & [0.00239] & {$[0.00225]$} & [0.00287] \\
\hline \multirow[t]{2}{*}{ Plateau } & -0.00518 & -0.00539 & 0.0382 \\
\hline & {$[0.0244]$} & [0.0220] & {$[0.0268]$} \\
\hline \multirow[t]{2}{*}{ Mountainous } & -0.00952 & 0.00443 & 0.000734 \\
\hline & {$[0.0212]$} & {$[0.0220]$} & [0.0273] \\
\hline Observations & 20,483 & 20,483 & 20,483 \\
\hline R-squared & 0.183 & 0.231 & 0.23 \\
\hline
\end{tabular}


Table A3 continued

\begin{tabular}{|c|c|c|c|}
\hline & \multicolumn{3}{|c|}{ 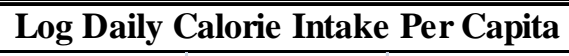 } \\
\hline & 25th & 50th & 75th \\
\hline \multirow[t]{2}{*}{ Log Wheat Flour Price } & $-0.0866 * * *$ & $-0.187^{* * *}$ & $-0.279 * * *$ \\
\hline & {$[0.0290]$} & {$[0.0268]$} & {$[0.0340]$} \\
\hline \multirow[t]{2}{*}{ Agricultural Household } & $0.0303 * * *$ & $0.0215^{* * *}$ & $0.0254 * * *$ \\
\hline & [0.00791] & {$[0.00744]$} & [0.00917] \\
\hline \multirow{2}{*}{$\begin{array}{l}\text { Log Real Value Monthly } \\
\text { Housing Per Capita }\end{array}$} & $-0.00970^{*}$ & -0.00513 & 0.00438 \\
\hline & {$[0.00510]$} & {$[0.00488]$} & {$[0.00565]$} \\
\hline \multirow{2}{*}{$\begin{array}{l}\text { Log Real Value Monthly } \\
\text { Durables Per Capita }\end{array}$} & $0.0329 * * *$ & $0.0344^{* * *}$ & $0.0336 * * *$ \\
\hline & {$[0.00370]$} & {$[0.00341]$} & {$[0.00462]$} \\
\hline \multirow{2}{*}{$\begin{array}{l}\text { Log Real Value Livestock } \\
\quad \text { Per Capita }\end{array}$} & $0.00578^{* * *}$ & $0.00541^{* * *}$ & $0.00509 * * *$ \\
\hline & {$[0.00101]$} & {$[0.000964]$} & {$[0.00130]$} \\
\hline \multirow[t]{2}{*}{ Log Kerosene Price } & $0.176^{* * *}$ & $0.217^{* * *}$ & $0.326^{* * *}$ \\
\hline & [0.0522] & [0.0452] & {$[0.0554]$} \\
\hline \multirow[t]{2}{*}{ Log Vegetable Oil Price } & 0.057 & 0.0294 & -0.00418 \\
\hline & [0.0465] & [0.0448] & {$[0.0556]$} \\
\hline \multirow[t]{2}{*}{ Log Local Rice Price } & $-0.120 * * *$ & $-0.0990 * * *$ & $-0.111^{* * *}$ \\
\hline & {$[0.0350]$} & {$[0.0301]$} & {$[0.0351]$} \\
\hline \multirow[t]{2}{*}{ Log Lamb Price } & $-0.158^{* *}$ & -0.00786 & 0.0426 \\
\hline & {$[0.0737]$} & [0.0647] & [0.0813] \\
\hline \multirow[t]{2}{*}{ Log Milk Price } & $-0.128 * * *$ & $-0.123^{* * *}$ & $-0.161^{* * *}$ \\
\hline & {$[0.0316]$} & {$[0.0285]$} & {$[0.0351]$} \\
\hline \multirow[t]{2}{*}{ Head Age } & 0.00601 & $0.0417^{* *}$ & $0.0591^{* *}$ \\
\hline & {$[0.0243]$} & {$[0.0211]$} & [0.0277] \\
\hline \multirow[t]{2}{*}{ Head Married } & -0.0146 & $-0.0198^{*}$ & $-0.0318^{* *}$ \\
\hline & {$[0.0120]$} & [0.0117] & {$[0.0146]$} \\
\hline \multirow[t]{2}{*}{ Head Literate } & 0.00476 & 0.00286 & 0.00699 \\
\hline & {$[0.00682]$} & {$[0.00655]$} & [0.00823] \\
\hline \multirow[t]{2}{*}{ Number Men } & -0.00124 & -0.00111 & -0.00453 \\
\hline & [0.00327] & {$[0.00340]$} & {$[0.00440]$} \\
\hline \multirow[t]{2}{*}{ Number Women } & 0.000764 & -0.00398 & $-0.00670^{*}$ \\
\hline & [0.00324] & {$[0.00290]$} & {$[0.00382]$} \\
\hline \multirow[t]{2}{*}{ Number Children } & $-0.0155^{* * *}$ & $-0.0184^{* * *}$ & $-0.0235^{* * *}$ \\
\hline & [0.00162] & {$[0.00162]$} & {$[0.00222]$} \\
\hline \multirow[t]{2}{*}{ Plateau } & 0.00628 & 0.00175 & 0.00868 \\
\hline & [0.0142] & {$[0.0141]$} & {$[0.0165]$} \\
\hline \multirow[t]{2}{*}{ Mountainous } & -0.000836 & 0.00897 & 0.015 \\
\hline & {$[0.0134]$} & {$[0.0140]$} & {$[0.0177]$} \\
\hline Observations & 20,483 & 20,483 & 20,483 \\
\hline R-squared & 0.163 & 0.194 & 0.177 \\
\hline
\end{tabular}

See Table A2 notes. 
Table A3 continued

\begin{tabular}{|c|c|c|c|}
\hline & \multicolumn{3}{|c|}{ Log Food Consumption Score } \\
\hline & 25th & 50th & 75th \\
\hline \multirow[t]{2}{*}{ Log Wheat Flour Price } & $-0.246 * * *$ & $-0.173 * * *$ & $-0.158^{* * *}$ \\
\hline & {$[0.0508]$} & {$[0.0305]$} & [0.0319] \\
\hline \multirow[t]{2}{*}{ Agricultural Household } & $0.0586^{* * *}$ & $0.0361 * * *$ & $0.0179 * *$ \\
\hline & {$[0.0148]$} & {$[0.00834]$} & {$[0.00834]$} \\
\hline \multirow{2}{*}{$\begin{array}{c}\text { Log Real Value Monthly } \\
\text { Housing Per Capita }\end{array}$} & $0.0456^{* * *}$ & $0.0415^{* * *}$ & $0.0322 * * *$ \\
\hline & [0.00995] & {$[0.00581]$} & {$[0.00525]$} \\
\hline \multirow{2}{*}{$\begin{array}{l}\text { Log Real Value Monthly } \\
\text { Durables Per Capita }\end{array}$} & $0.0627^{* * *}$ & $0.0490 * * *$ & $0.0553^{* * *}$ \\
\hline & [0.00573] & {$[0.00375]$} & [0.00424] \\
\hline \multirow{2}{*}{$\begin{array}{l}\text { Log Real Value Livestock } \\
\text { Per Capita }\end{array}$} & $0.0303^{* * *}$ & $0.0163^{* * *}$ & $0.00762^{* * *}$ \\
\hline & [0.00232] & {$[0.00123]$} & [0.00118] \\
\hline \multirow[t]{2}{*}{ Log Kerosene Price } & $-0.180 * *$ & $-0.0888^{*}$ & 0.0648 \\
\hline & [0.0891] & [0.0458] & [0.0495] \\
\hline \multirow[t]{2}{*}{ Log Vegetable Oil Price } & 0.0192 & -0.0525 & $-0.120 * *$ \\
\hline & [0.0793] & [0.0479] & [0.0481] \\
\hline \multirow[t]{2}{*}{ Log Local Rice Price } & $0.205^{* * *}$ & $0.108^{* * *}$ & 0.00474 \\
\hline & [0.0492] & {$[0.0316]$} & {$[0.0348]$} \\
\hline \multirow[t]{2}{*}{ Log Lamb Price } & $0.244^{* *}$ & -0.108 & $-0.296 * * *$ \\
\hline & [0.118] & {$[0.0686]$} & [0.0682] \\
\hline \multirow[t]{2}{*}{ Log Milk Price } & $-0.0797 *$ & $-0.109 * * *$ & $-0.159 * * *$ \\
\hline & [0.0471] & [0.0289] & [0.0331] \\
\hline \multirow[t]{2}{*}{ Head Age } & 0.0526 & 0.00479 & 0.00531 \\
\hline & [0.0388] & {$[0.0230]$} & [0.0233] \\
\hline \multirow[t]{2}{*}{ Head Married } & $0.0828 * * *$ & $0.0645^{* * *}$ & $0.0448 * * *$ \\
\hline & {$[0.0222]$} & {$[0.0115]$} & [0.0128] \\
\hline \multirow[t]{2}{*}{ Head Literate } & $-0.0654^{* * *}$ & $-0.0397^{* * *}$ & $-0.0353^{* * *}$ \\
\hline & [0.0113] & {$[0.00710]$} & {$[0.00742]$} \\
\hline \multirow[t]{2}{*}{ Number Men } & $0.0211^{* * *}$ & $0.0153^{* * *}$ & $0.0231^{* * *}$ \\
\hline & [0.00539] & {$[0.00347]$} & {$[0.00401]$} \\
\hline \multirow[t]{2}{*}{ Number Women } & $0.0178^{* * *}$ & $0.0149 * * *$ & $0.0126 * * *$ \\
\hline & [0.00490] & {$[0.00306]$} & {$[0.00337]$} \\
\hline \multirow[t]{2}{*}{ Number Children } & $0.0162^{* * *}$ & $0.0118^{* * *}$ & $0.0128 * * *$ \\
\hline & [0.00242] & {$[0.00154]$} & [0.00175] \\
\hline \multirow[t]{2}{*}{ Plateau } & -0.0376 & 0.00798 & $0.0366^{* *}$ \\
\hline & [0.0264] & [0.0154] & [0.0154] \\
\hline \multirow[t]{2}{*}{ Mountainous } & -0.034 & -0.00204 & 0.0181 \\
\hline & {$[0.0246]$} & [0.0153] & {$[0.0166]$} \\
\hline Observations & 20,483 & 20,483 & 20,483 \\
\hline R-squared & 0.268 & 0.284 & 0.237 \\
\hline
\end{tabular}

See Table A2 notes. 
Table A4. Differential impact of wheat flour price increases using the OLS estimator

\begin{tabular}{|c|c|c|c|}
\hline & $\begin{array}{l}\text { Log Real Value of } \\
\text { Monthly Food } \\
\text { Consumption }\end{array}$ & $\begin{array}{l}\text { Log Daily Calorie } \\
\text { Intake Per Capita }\end{array}$ & $\begin{array}{c}\text { Log Food } \\
\text { Consumption Score }\end{array}$ \\
\hline \multirow[t]{2}{*}{ Log Wheat Flour Price } & $-0.437^{* * *}$ & $-0.138^{* * *}$ & $-0.229 * * *$ \\
\hline & {$[0.0401]$} & {$[0.0263]$} & {$[0.0300]$} \\
\hline \multirow{2}{*}{$\begin{array}{l}\text { Log Wheat Flour Price X } \\
\text { Agricultural Household }\end{array}$} & 0.0196 & $-0.0750 * * *$ & $0.0665^{* * *}$ \\
\hline & [0.0288] & [0.0203] & {$[0.0195]$} \\
\hline \multirow[t]{2}{*}{ Agricultural Household } & -0.0296 & $0.277^{* * *}$ & $-0.188 * * *$ \\
\hline & [0.0971] & [0.0685] & [0.0649] \\
\hline \multirow{2}{*}{$\begin{array}{l}\text { Log Real Value Monthly } \\
\text { Housing Per Capita }\end{array}$} & $0.0367^{* * *}$ & -0.00538 & $0.0385^{* * *}$ \\
\hline & [0.00685] & [0.00440] & {$[0.00482]$} \\
\hline \multirow{2}{*}{$\begin{array}{l}\text { Log Real Value Monthly } \\
\text { Durables Per Capita }\end{array}$} & $0.0996 * * *$ & $0.0372^{* * *}$ & $0.0573^{* * *}$ \\
\hline & [0.00444] & [0.00332] & [0.00303] \\
\hline \multirow{2}{*}{$\begin{array}{l}\text { Log Real Value Livestock } \\
\text { Per Capita }\end{array}$} & $0.0133^{* * *}$ & $0.00675^{* * *}$ & $0.0165^{* * *}$ \\
\hline & {$[0.00128]$} & [0.000930] & [0.000999] \\
\hline \multirow[t]{2}{*}{ Log Kerosene Price } & $0.236 * * *$ & $0.169 * * *$ & -0.0192 \\
\hline & [0.0644] & {$[0.0461]$} & [0.0476] \\
\hline \multirow[t]{2}{*}{ Log Vegetable Oil Price } & $-0.141^{* *}$ & 0.0147 & -0.0338 \\
\hline & [0.0598] & [0.0442] & [0.0440] \\
\hline \multirow[t]{2}{*}{ Log Local Rice Price } & -0.00662 & $-0.107^{* * *}$ & $0.0710^{* * *}$ \\
\hline & [0.0399] & {$[0.0263]$} & [0.0262] \\
\hline \multirow[t]{2}{*}{ Log Lamb Price } & -0.128 & -0.0492 & -0.0196 \\
\hline & [0.0902] & {$[0.0628]$} & [0.0642] \\
\hline \multirow[t]{2}{*}{ Log Milk Price } & $-0.140^{* * *}$ & $-0.145^{* * *}$ & $-0.101 * * *$ \\
\hline & {$[0.0377]$} & [0.0279] & [0.0268] \\
\hline \multirow[t]{2}{*}{ Head Age } & 0.0013 & 0.0301 & 0.0225 \\
\hline & [0.0263] & [0.0212] & {$[0.0200]$} \\
\hline \multirow[t]{2}{*}{ Head Married } & 0.00756 & $-0.0324^{* * *}$ & $0.0622^{* * *}$ \\
\hline & [0.0144] & {$[0.0106]$} & [0.0101] \\
\hline \multirow[t]{2}{*}{ Head Literate } & $-0.0370 * * *$ & -0.000657 & $-0.0448 * * *$ \\
\hline & [0.00776] & [0.00608] & [0.00573] \\
\hline \multirow[t]{2}{*}{ Number Men } & 0.00196 & -0.00405 & $0.0199 * * *$ \\
\hline & [0.00382] & {$[0.00302]$} & [0.00294] \\
\hline \multirow[t]{2}{*}{ Number Women } & -0.00194 & $-0.00495^{*}$ & $0.0166^{* * *}$ \\
\hline & [0.00353] & {$[0.00274]$} & {$[0.00255]$} \\
\hline \multirow[t]{2}{*}{ Number Children } & $-0.0208 * * *$ & $-0.0213^{* * *}$ & $0.0129 * * *$ \\
\hline & [0.00177] & [0.00144] & [0.00127] \\
\hline \multirow[t]{2}{*}{ Plateau } & 0.00375 & -0.000291 & -0.0044 \\
\hline & {$[0.0210]$} & [0.0141] & [0.0153] \\
\hline \multirow[t]{2}{*}{ Mountainous } & -0.00372 & 0.00119 & -0.0115 \\
\hline & [0.0196] & [0.0141] & [0.0139] \\
\hline Observations & 20,483 & 20,483 & 20,483 \\
\hline R-squared & 0.353 & 0.251 & 0.393 \\
\hline
\end{tabular}


Table A5. Differential impact of wheat flour price increase using the unconditional quantile regression estimator

\begin{tabular}{|c|c|c|c|}
\hline & \multicolumn{3}{|c|}{ Log Real Value of Monthly Food Consumption } \\
\hline & 25th & 50th & 75th \\
\hline \multirow[t]{2}{*}{ Log Wheat Flour Price } & $-0.220 * * *$ & $-0.416^{* * *}$ & $-0.615^{* * *}$ \\
\hline & [0.0460] & {$[0.0540]$} & [0.0608] \\
\hline \multirow{2}{*}{$\begin{array}{l}\text { Log Wheat Flour Price X } \\
\text { Agricultural Household }\end{array}$} & -0.0355 & -0.0275 & -0.0072 \\
\hline & [0.0349] & {$[0.0336]$} & [0.0410] \\
\hline \multirow[t]{2}{*}{ Agricultural Household } & 0.155 & 0.123 & 0.0644 \\
\hline & [0.116] & [0.113] & [0.140] \\
\hline \multirow{2}{*}{$\begin{array}{c}\text { Log Real Value Monthly } \\
\text { Housing Per Capita }\end{array}$} & $0.0208^{* *}$ & $0.0394^{* * *}$ & $0.0410^{* * *}$ \\
\hline & {$[0.00866]$} & {$[0.00768]$} & {$[0.00915]$} \\
\hline \multirow{2}{*}{$\begin{array}{c}\text { Log Real Value Monthly } \\
\text { Durables Per Capita }\end{array}$} & $0.0812^{* * *}$ & $0.0806^{* * *}$ & $0.107^{* * *}$ \\
\hline & {$[0.00548]$} & {$[0.00538]$} & [0.00732] \\
\hline \multirow{2}{*}{$\begin{array}{l}\text { Log Real Value Livestock } \\
\text { Per Capita }\end{array}$} & $0.0118^{* * *}$ & $0.0135^{* * *}$ & $0.0115^{* * *}$ \\
\hline & [0.00158] & {$[0.00155]$} & [0.00196] \\
\hline \multirow[t]{2}{*}{ Log Kerosene Price } & $0.210 * *$ & $0.137^{* *}$ & $0.271^{* * *}$ \\
\hline & [0.0831] & [0.0697] & [0.0899] \\
\hline \multirow[t]{2}{*}{ Log Vegetable Oil Price } & -0.075 & -0.0713 & -0.119 \\
\hline & {$[0.0623]$} & {$[0.0720]$} & [0.0940] \\
\hline \multirow[t]{2}{*}{ Log Local Rice Price } & -0.0602 & -0.00452 & 0.0286 \\
\hline & [0.0543] & {$[0.0484]$} & {$[0.0589]$} \\
\hline \multirow[t]{2}{*}{ Log Lamb Price } & -0.141 & $-0.200^{* *}$ & $-0.258^{*}$ \\
\hline & {$[0.106]$} & {$[0.0961]$} & {$[0.134]$} \\
\hline \multirow[t]{2}{*}{ Log Milk Price } & $-0.109 * *$ & $-0.0817^{* *}$ & $-0.173 * * *$ \\
\hline & [0.0434] & {$[0.0416]$} & {$[0.0578]$} \\
\hline \multirow[t]{2}{*}{ Head Age } & 0.02 & 0.00578 & -0.00111 \\
\hline & {$[0.0358]$} & {$[0.0321]$} & [0.0413] \\
\hline \multirow[t]{2}{*}{ Head Married } & $0.0461^{* *}$ & 0.024 & -0.00441 \\
\hline & [0.0189] & {$[0.0170]$} & {$[0.0223]$} \\
\hline \multirow[t]{2}{*}{ Head Literate } & $-0.0247^{* *}$ & $-0.0350^{* * *}$ & $-0.0435^{* * *}$ \\
\hline & {$[0.0104]$} & {$[0.00945]$} & {$[0.0127]$} \\
\hline \multirow[t]{2}{*}{ Number Men } & -0.00246 & $0.00779 *$ & 0.00366 \\
\hline & {$[0.00474]$} & {$[0.00461]$} & [0.00589] \\
\hline \multirow[t]{2}{*}{ Number Women } & 0.00197 & -0.00315 & 0.00264 \\
\hline & {$[0.00437]$} & {$[0.00415]$} & {$[0.00523]$} \\
\hline \multirow[t]{2}{*}{ Number Children } & $-0.0150^{* * *}$ & $-0.0183^{* * *}$ & $-0.0236 * * *$ \\
\hline & {$[0.00223]$} & {$[0.00221]$} & [0.00269] \\
\hline \multirow[t]{2}{*}{ Plateau } & -0.00532 & -0.0055 & 0.0382 \\
\hline & [0.0234] & [0.0220] & [0.0280] \\
\hline \multirow[t]{2}{*}{ Mountainous } & -0.00955 & 0.00441 & 0.000728 \\
\hline & [0.0218] & {$[0.0212]$} & {$[0.0277]$} \\
\hline Observations & 20,483 & 20,483 & 20,483 \\
\hline R-squared & 0.183 & 0.231 & 0.23 \\
\hline
\end{tabular}

See Table A2 notes. 
Table A5 continued

\begin{tabular}{|c|c|c|c|}
\hline & \multicolumn{3}{|c|}{ Log Daily Calorie Intake Per Capita } \\
\hline & 25th & 50th & 75th \\
\hline \multirow[t]{2}{*}{ Log Wheat Flour Price } & $-0.0641^{* *}$ & $-0.136^{* * *}$ & $-0.237^{* * *}$ \\
\hline & [0.0298] & [0.0285] & [0.0356] \\
\hline \multirow{2}{*}{$\begin{array}{l}\text { Log Wheat Flour Price X } \\
\text { Agricultural Household }\end{array}$} & -0.037 & $-0.0837^{* * *}$ & $-0.0700^{* * *}$ \\
\hline & [0.0231] & {$[0.0206]$} & {$[0.0267]$} \\
\hline \multirow[t]{2}{*}{ Agricultural Household } & $0.152^{* *}$ & $0.297 * * *$ & $0.256 * * *$ \\
\hline & {$[0.0771]$} & {$[0.0697]$} & {$[0.0911]$} \\
\hline \multirow{2}{*}{$\begin{array}{l}\text { Log Real Value Monthly } \\
\text { Housing Per Capita }\end{array}$} & $-0.00994^{* *}$ & -0.00568 & 0.00393 \\
\hline & [0.00497] & [0.00457] & {$[0.00557]$} \\
\hline \multirow{2}{*}{$\begin{array}{l}\text { Log Real Value Monthly } \\
\text { Durables Per Capita }\end{array}$} & $0.0327^{* * *}$ & $0.0342^{* * *}$ & $0.0333^{* * *}$ \\
\hline & [0.00366] & [0.00351] & [0.00466] \\
\hline \multirow{2}{*}{$\begin{array}{l}\text { Log Real Value Livestock } \\
\text { Per Capita }\end{array}$} & $0.00581^{* * *}$ & $0.00547^{* * *}$ & $0.00514^{* * *}$ \\
\hline & {$[0.00100]$} & {$[0.000978]$} & {$[0.00132]$} \\
\hline \multirow[t]{2}{*}{ Log Kerosene Price } & $0.171^{* * *}$ & $0.205^{* * *}$ & $0.316^{* * *}$ \\
\hline & {$[0.0500]$} & [0.0449] & {$[0.0556]$} \\
\hline \multirow[t]{2}{*}{ Log Vegetable Oil Price } & 0.0576 & 0.0306 & -0.00319 \\
\hline & [0.0463] & {$[0.0444]$} & [0.0555] \\
\hline \multirow[t]{2}{*}{ Log Local Rice Price } & $-0.119 * * *$ & $-0.0960 * * *$ & $-0.109 * * *$ \\
\hline & {$[0.0341]$} & {$[0.0284]$} & {$[0.0347]$} \\
\hline \multirow[t]{2}{*}{ Log Lamb Price } & $-0.158^{* *}$ & -0.00828 & 0.0423 \\
\hline & {$[0.0745]$} & {$[0.0640]$} & {$[0.0806]$} \\
\hline \multirow[t]{2}{*}{ Log Milk Price } & $-0.129 * * *$ & $-0.125^{* * *}$ & $-0.163^{* * *}$ \\
\hline & {$[0.0310]$} & [0.0289] & {$[0.0340]$} \\
\hline \multirow[t]{2}{*}{ Head Age } & 0.00683 & $0.0435^{* *}$ & $0.0607^{* *}$ \\
\hline & [0.0234] & [0.0222] & [0.0282] \\
\hline \multirow[t]{2}{*}{ Head Married } & -0.0146 & $-0.0198 *$ & $-0.0319 * *$ \\
\hline & {$[0.0125]$} & [0.0110] & {$[0.0146]$} \\
\hline \multirow[t]{2}{*}{ Head Literate } & 0.00453 & 0.00233 & 0.00655 \\
\hline & [0.00679] & {$[0.00657]$} & [0.00839] \\
\hline \multirow[t]{2}{*}{ Number Men } & -0.00127 & -0.00117 & -0.00458 \\
\hline & [0.00326] & [0.00343] & [0.00417] \\
\hline \multirow[t]{2}{*}{ Number Women } & 0.000798 & -0.0039 & $-0.00663 *$ \\
\hline & [0.00322] & [0.00295] & {$[0.00357]$} \\
\hline \multirow[t]{2}{*}{ Number Children } & $-0.0155^{* * *}$ & $-0.0185^{* * *}$ & $-0.0236^{* * *}$ \\
\hline & {$[0.00170]$} & [0.00163] & {$[0.00220]$} \\
\hline \multirow[t]{2}{*}{ Plateau } & 0.00614 & 0.00141 & 0.0084 \\
\hline & {$[0.0140]$} & {$[0.0138]$} & [0.0179] \\
\hline \multirow[t]{2}{*}{ Mountainous } & -0.000867 & 0.0089 & 0.015 \\
\hline & [0.0130] & {$[0.0144]$} & [0.0188] \\
\hline Observations & 20,483 & 20,483 & 20,483 \\
\hline R-squared & 0.163 & 0.195 & 0.177 \\
\hline
\end{tabular}

See Table A2 notes. 
Table A5 continued

\begin{tabular}{|c|c|c|c|}
\hline & \multicolumn{3}{|c|}{ Log Food Consumption Score } \\
\hline & 25th & 50th & 75th \\
\hline \multirow[t]{2}{*}{ Log Wheat Flour Price } & $-0.317^{* * *}$ & $-0.201 * * *$ & $-0.156 * * *$ \\
\hline & [0.0551] & [0.0316] & [0.0341] \\
\hline \multirow{2}{*}{$\begin{array}{l}\text { Log Wheat Flour Price X } \\
\text { Agricultural Household }\end{array}$} & $0.117^{* * *}$ & $0.0459 * *$ & -0.00321 \\
\hline & [0.0368] & {$[0.0215]$} & {$[0.0240]$} \\
\hline \multirow[t]{2}{*}{ Agricultural Household } & $-0.328^{* * *}$ & -0.115 & 0.0284 \\
\hline & [0.123] & {$[0.0715]$} & {$[0.0812]$} \\
\hline \multirow{2}{*}{$\begin{array}{l}\text { Log Real Value Monthly } \\
\text { Housing Per Capita }\end{array}$} & $0.0464^{* * *}$ & $0.0418^{* * *}$ & $0.0322 * * *$ \\
\hline & [0.00965] & {$[0.00593]$} & {$[0.00536]$} \\
\hline \multirow{2}{*}{$\begin{array}{l}\text { Log Real Value Monthly } \\
\text { Durables Per Capita }\end{array}$} & $0.0630^{* * *}$ & $0.0491^{* * *}$ & $0.0553^{* * *}$ \\
\hline & {$[0.00585]$} & {$[0.00371]$} & {$[0.00415]$} \\
\hline \multirow{2}{*}{$\begin{array}{l}\text { Log Real Value Livestock } \\
\text { Per Capita }\end{array}$} & $0.0302^{* * *}$ & $0.0163^{* * *}$ & $0.00762^{* * *}$ \\
\hline & {$[0.00230]$} & {$[0.00123]$} & [0.00113] \\
\hline \multirow[t]{2}{*}{ Log Kerosene Price } & $-0.163^{*}$ & $-0.0823^{*}$ & 0.0643 \\
\hline & [0.0900] & [0.0483] & [0.0473] \\
\hline \multirow[t]{2}{*}{ Log Vegetable Oil Price } & 0.0175 & -0.0532 & $-0.120^{* *}$ \\
\hline & [0.0803] & {$[0.0437]$} & [0.0496] \\
\hline \multirow[t]{2}{*}{ Log Local Rice Price } & $0.201^{* * *}$ & $0.107^{* * *}$ & 0.00486 \\
\hline & {$[0.0501]$} & [0.0303] & {$[0.0376]$} \\
\hline \multirow[t]{2}{*}{ Log Lamb Price } & $0.244^{* *}$ & -0.108 & $-0.296^{* * *}$ \\
\hline & [0.115] & {$[0.0685]$} & {$[0.0696]$} \\
\hline \multirow[t]{2}{*}{ Log Milk Price } & $-0.0763^{*}$ & $-0.108^{* * *}$ & $-0.160 * * *$ \\
\hline & [0.0454] & [0.0286] & [0.0336] \\
\hline \multirow[t]{2}{*}{ Head Age } & 0.05 & 0.00378 & 0.00538 \\
\hline & {$[0.0374]$} & {$[0.0240]$} & [0.0233] \\
\hline \multirow[t]{2}{*}{ Head Married } & $0.0829 * * *$ & $0.0645^{* * *}$ & $0.0448^{* * *}$ \\
\hline & [0.0213] & {$[0.0116]$} & {$[0.0122]$} \\
\hline \multirow[t]{2}{*}{ Head Literate } & $-0.0646 * * *$ & $-0.0394^{* * *}$ & $-0.0354^{* * *}$ \\
\hline & [0.0108] & {$[0.00694]$} & {$[0.00771]$} \\
\hline \multirow[t]{2}{*}{ Number Men } & $0.0212^{* * *}$ & $0.0154^{* * *}$ & $0.0231^{* * *}$ \\
\hline & [0.00551] & [0.00338] & [0.00378] \\
\hline \multirow[t]{2}{*}{ Number Women } & $0.0177^{* * *}$ & $0.0149^{* * *}$ & $0.0126^{* * *}$ \\
\hline & {$[0.00495]$} & [0.00309] & [0.00339] \\
\hline \multirow[t]{2}{*}{ Number Children } & $0.0163^{* * *}$ & $0.0118^{* * *}$ & $0.0128 * * *$ \\
\hline & {$[0.00236]$} & [0.00153] & {$[0.00176]$} \\
\hline \multirow[t]{2}{*}{ Plateau } & -0.0372 & 0.00816 & $0.0366^{* *}$ \\
\hline & [0.0260] & [0.0153] & [0.0159] \\
\hline \multirow[t]{2}{*}{ Mountainous } & -0.0339 & -0.002 & 0.0181 \\
\hline & {$[0.0246]$} & {$[0.0151]$} & {$[0.0162]$} \\
\hline Observations & 20,483 & 20,483 & 20,483 \\
\hline R-squared & 0.269 & 0.284 & 0.237 \\
\hline
\end{tabular}


Table A6. Unconditional quantile regression estimates at policy-relevant cutoffs

\begin{tabular}{|c|c|c|c|c|}
\hline & $\begin{array}{c}\text { Real Value of } \\
\text { Monthly Food } \\
\text { Consumption = } \\
687.13\end{array}$ & $\begin{array}{c}\text { Daily Calorie } \\
\text { Intake Per Capita } \\
=\mathbf{2 , 1 0 0}\end{array}$ & $\begin{array}{c}\text { Food Consumption } \\
\text { Score }=\mathbf{2 8}\end{array}$ & $\begin{array}{c}\text { Food Consumption } \\
\text { Score }=42\end{array}$ \\
\hline \multirow[t]{2}{*}{ Log Wheat Flour Price } & $-0.298 * * *$ & $-0.115^{* * *}$ & $-0.163^{* * *}$ & $-0.256 * * *$ \\
\hline & [0.0437] & [0.0279] & [0.0565] & [0.0518] \\
\hline \multirow[t]{2}{*}{ Agricultural Household } & $0.0300 * *$ & $0.0292 * * *$ & 0.0103 & $0.0426 * * *$ \\
\hline & [0.0119] & {$[0.00803]$} & {$[0.0192]$} & {$[0.0154]$} \\
\hline \multirow{2}{*}{$\begin{array}{c}\text { Log Real Value Monthly } \\
\text { Housing Per Capita }\end{array}$} & $0.0339 * * *$ & $-0.0101^{* *}$ & $0.0345^{* * *}$ & $0.0378^{* * *}$ \\
\hline & {$[0.00790]$} & {$[0.00476]$} & {$[0.0101]$} & [0.0101] \\
\hline \multirow{2}{*}{$\begin{array}{c}\text { Log Real Value Monthly } \\
\text { Durables Per Capita }\end{array}$} & $0.0771^{* * *}$ & $0.0353^{* * *}$ & $0.0613^{* * *}$ & $0.0581 * * *$ \\
\hline & {$[0.00552]$} & [0.00345] & [0.00855] & {$[0.00592]$} \\
\hline \multirow{2}{*}{$\begin{array}{l}\text { Log Real Value Livestock } \\
\text { Per Capita }\end{array}$} & $0.0140 * * *$ & $0.00604^{* * *}$ & $0.0199 * * *$ & $0.0281^{* * *}$ \\
\hline & {$[0.00152]$} & [0.00103] & [0.00290] & {$[0.00221]$} \\
\hline \multirow[t]{2}{*}{ Log Kerosene Price } & $0.129 *$ & $0.174^{* * *}$ & -0.209 & $-0.237 * *$ \\
\hline & [0.0780] & [0.0498] & {$[0.146]$} & {$[0.101]$} \\
\hline \multirow[t]{2}{*}{ Log Vegetable Oil Price } & -0.0851 & 0.0603 & 0.0795 & 0.0491 \\
\hline & {$[0.0636]$} & {$[0.0426]$} & [0.103] & {$[0.0831]$} \\
\hline \multirow[t]{2}{*}{ Log Local Rice Price } & -0.0378 & $-0.133 * * *$ & 0.0709 & $0.198^{* * *}$ \\
\hline & {$[0.0527]$} & {$[0.0347]$} & [0.0561] & [0.0497] \\
\hline \multirow[t]{2}{*}{ Log Lamb Price } & -0.167 & -0.0955 & $0.425 * *$ & $0.283^{* *}$ \\
\hline & {$[0.107]$} & [0.0680] & {$[0.166]$} & {$[0.125]$} \\
\hline \multirow[t]{2}{*}{ Log Milk Price } & $-0.0932^{* *}$ & $-0.115^{* * *}$ & 0.0404 & -0.0143 \\
\hline & [0.0419] & {$[0.0288]$} & [0.0686] & [0.0524] \\
\hline \multirow[t]{2}{*}{ Head Age } & -0.00678 & 0.03 & 0.0296 & $0.107^{* * *}$ \\
\hline & [0.0350] & [0.0228] & [0.0514] & [0.0401] \\
\hline \multirow[t]{2}{*}{ Head Married } & $0.0428^{* *}$ & -0.0183 & $0.0728^{* *}$ & $0.0631^{* * *}$ \\
\hline & [0.0175] & [0.0121] & [0.0298] & {$[0.0237]$} \\
\hline \multirow[t]{2}{*}{ Head Literate } & $-0.0208^{* *}$ & -0.0018 & $-0.0231^{*}$ & $-0.0584^{* * *}$ \\
\hline & {$[0.00977]$} & {$[0.00680]$} & [0.0139] & [0.0119] \\
\hline \multirow[t]{2}{*}{ Number Men } & 0.00286 & -0.000983 & $0.0190 * * *$ & $0.0159 * * *$ \\
\hline & [0.00475] & [0.00335] & [0.00634] & {$[0.00567]$} \\
\hline \multirow[t]{2}{*}{ Number Women } & 0.00133 & -0.00378 & $0.0171^{* * *}$ & $0.0209 * * *$ \\
\hline & [0.00443] & {$[0.00305]$} & {$[0.00607]$} & {$[0.00522]$} \\
\hline \multirow[t]{2}{*}{ Number Children } & $-0.0153 * * *$ & $-0.0159 * * *$ & $0.00585^{*}$ & $0.0147^{* * *}$ \\
\hline & {$[0.00222]$} & [0.00168] & [0.00316] & {$[0.00256]$} \\
\hline \multirow[t]{2}{*}{ Plateau } & 0.00114 & 0.0019 & -0.0577 & -0.0107 \\
\hline & [0.0247] & [0.0140] & [0.0397] & [0.0281] \\
\hline \multirow[t]{2}{*}{ Mountainous } & 0.00193 & -0.00515 & $-0.0779 * *$ & -0.0127 \\
\hline & [0.0220] & [0.0129] & [0.0318] & {$[0.0260]$} \\
\hline Observations & 20,483 & 20,483 & 20,483 & 20,483 \\
\hline R-squared & 0.207 & 0.174 & 0.101 & 0.254 \\
\hline
\end{tabular}


Table A7. Differential impact of wheat flour price increases

using the unconditional quantile regression estimator at policy-rele vant cutoffs

\begin{tabular}{|c|c|c|c|c|}
\hline & \begin{tabular}{|c|} 
Real Value of \\
Monthly Food \\
Consumption $=687.13$
\end{tabular} & $\begin{array}{c}\text { Daily Calorie Intake } \\
\text { Per Capita }=\mathbf{2 , 1 0 0}\end{array}$ & $\begin{array}{c}\text { Food Consumption } \\
\text { Score }=28\end{array}$ & $\begin{array}{c}\text { Food Consumption } \\
\text { Score }=42\end{array}$ \\
\hline \multirow[t]{2}{*}{ Log Wheat Flour Price } & $-0.282^{* * *}$ & $-0.0813^{* * *}$ & $-0.218^{* * *}$ & $-0.340 * * *$ \\
\hline & [0.0454] & [0.0287] & [0.0678] & [0.0588] \\
\hline \multirow{2}{*}{$\begin{array}{l}\text { Log Wheat Flour Price X } \\
\text { Agricultural Household }\end{array}$} & -0.0271 & $-0.0550 * * *$ & $0.0905^{* *}$ & $0.139 * * *$ \\
\hline & [0.0316] & {$[0.0212]$} & [0.0461] & [0.0364] \\
\hline \multirow[t]{2}{*}{ Agricultural Household } & 0.119 & $0.210^{* * *}$ & $-0.288^{*}$ & $-0.415^{* * *}$ \\
\hline & {$[0.106]$} & {$[0.0714]$} & {$[0.149]$} & {$[0.121]$} \\
\hline \multirow{2}{*}{$\begin{array}{l}\text { Log Real Value Monthly } \\
\text { Housing Per Capita }\end{array}$} & $0.0337^{* * *}$ & $-0.0104^{* *}$ & $0.0351^{* * *}$ & $0.0387^{* * *}$ \\
\hline & {$[0.00776]$} & {$[0.00481]$} & {$[0.00981]$} & {$[0.0101]$} \\
\hline \multirow{2}{*}{$\begin{array}{c}\text { Log Real Value Monthly } \\
\text { Durables Per Capita }\end{array}$} & $0.0770 * * *$ & $0.0351^{* * *}$ & $0.0616^{* * *}$ & $0.0585^{* * *}$ \\
\hline & {$[0.00550]$} & {$[0.00358]$} & [0.00868] & {$[0.00580]$} \\
\hline \multirow{2}{*}{$\begin{array}{l}\text { Log Real Value Livestock } \\
\text { Per Capita }\end{array}$} & $0.0141^{* * *}$ & $0.00608^{* * *}$ & $0.0198^{* * *}$ & $0.0280^{* * *}$ \\
\hline & [0.00150] & [0.000999] & {$[0.00286]$} & [0.00235] \\
\hline \multirow[t]{2}{*}{ Log Kerosene Price } & 0.125 & $0.167^{* * *}$ & -0.196 & $-0.217^{* *}$ \\
\hline & [0.0762] & [0.0498] & [0.144] & [0.102] \\
\hline \multirow[t]{2}{*}{ Log Vegetable Oil Price } & -0.0847 & 0.0611 & 0.0782 & 0.0471 \\
\hline & [0.0673] & [0.0445] & {$[0.103]$} & [0.0859] \\
\hline \multirow[t]{2}{*}{ Log Local Rice Price } & -0.0368 & $-0.131^{* * *}$ & 0.0676 & $0.193^{* * *}$ \\
\hline & [0.0509] & [0.0326] & [0.0527] & {$[0.0500]$} \\
\hline \multirow[t]{2}{*}{ Log Lamb Price } & -0.167 & -0.0958 & $0.425^{* *}$ & $0.284^{* *}$ \\
\hline & {$[0.106]$} & [0.0709] & {$[0.168]$} & [0.124] \\
\hline \multirow[t]{2}{*}{ Log Milk Price } & $-0.0940 * *$ & $-0.117^{* * *}$ & 0.043 & -0.0103 \\
\hline & [0.0432] & [0.0299] & [0.0695] & [0.0475] \\
\hline \multirow[t]{2}{*}{ Head Age } & -0.00618 & 0.0312 & 0.0276 & $0.104^{* *}$ \\
\hline & [0.0332] & [0.0233] & [0.0548] & [0.0423] \\
\hline \multirow[t]{2}{*}{ Head Married } & $0.0428 * *$ & -0.0183 & $0.0729 * *$ & $0.0633^{* * *}$ \\
\hline & [0.0175] & [0.0120] & [0.0292] & [0.0233] \\
\hline \multirow[t]{2}{*}{ Head Literate } & $-0.0210^{* *}$ & -0.00215 & $-0.0225^{*}$ & $-0.0575^{* * *}$ \\
\hline & [0.00995] & [0.00669] & [0.0135] & {$[0.0122]$} \\
\hline \multirow[t]{2}{*}{ Number Men } & 0.00284 & -0.00102 & $0.0191 * * *$ & $0.0159 * * *$ \\
\hline & [0.00469] & [0.00330] & [0.00637] & [0.00584] \\
\hline \multirow[t]{2}{*}{ Number Women } & 0.00136 & -0.00373 & $0.0170^{* * *}$ & $0.0207^{* * *}$ \\
\hline & [0.00453] & [0.00314] & [0.00591] & [0.00543] \\
\hline \multirow[t]{2}{*}{ Number Children } & $-0.0153^{* * *}$ & $-0.0160 * * *$ & $0.00595^{*}$ & $0.0148^{* * *}$ \\
\hline & [0.00215] & [0.00161] & [0.00319] & [0.00250] \\
\hline \multirow[t]{2}{*}{ Plateau } & 0.00104 & 0.00168 & -0.0573 & -0.0102 \\
\hline & [0.0232] & [0.0138] & [0.0415] & [0.0287] \\
\hline \multirow[t]{2}{*}{ Mountainous } & 0.0019 & -0.00519 & $-0.0778^{* *}$ & -0.0126 \\
\hline & [0.0211] & {$[0.0130]$} & [0.0333] & [0.0252] \\
\hline Observations & 20,483 & 20,483 & 20,483 & 20,483 \\
\hline R-squared & 0.207 & 0.175 & 0.102 & 0.255 \\
\hline
\end{tabular}

See Table A2 notes. 